\title{
INDUSTRY LIFE CYCLES OF A RESOURCE TOWN IN FINLAND - THE CASE OF LIEKSA
}

\author{
Maija Halonen ${ }^{1}$, Juha Kotilainen ${ }^{2}$, Markku Tykkyläinen ${ }^{3}$, Eero Vatanen ${ }^{4}$
}

Received 21 November 2014; Accepted 25 February 2015

\begin{abstract}
The article aims to show how local industry life cycles impact the development of Finnish resource-based rural towns. This study reveals five long-term and overlapping industry cycles which were based on natural resources, assembly industries and service production. In general, the cycles have shortened over time. Transitions from cycle to cycle were enabled by the phases of resilience, which were highly dependent on political and economic processes at different scales. However, the political interventions of the last decades were unable to compensate for the disadvantages in competitiveness of this remote area and lay sustainable foundations for new industries. In the long run, the only exception has been the forest-related processing industry which has a capacity to renew its own operations and adapt to changing market situations. The results demonstrate the high significance of absolute advantage in rural development.
\end{abstract}

Keywords: industry life cycles; resource dependence; local resilience; employment; regional policy; forested areas; Finland

Abstrakti: Suomalaisten resurssiperustaisten maaseutukuntien kehitykseen ovat vaikuttaneet keskeisesti paikallisten toimialojen elinkaaret. Tutkimuskohteessa havaitut viisi toisiinsa limittyvää sykliä ovat perustuneet paikallisiin luonnonvaroihin, tuotuja raakaaineita ja puolivalmisteita käyttävään teollisuuteen ja palvelujen tuotantoon. Teollisella kaudella yksittäisen elinkaaren pituus on lyhentynyt. Syklistä toiseen siirtymiseen ovat vaikuttaneet eritasoiset poliittiset ja taloudelliset uusiutumisvaiheet. Viime vuosikymmenten poliittiset interventiot eivät ole kyenneet kompensoimaan tutkitun resurssiperiferian heikkoa kilpailukykyä ja luomaan kestävää perustaa uusille aloille. Parhaiten muuttuviin markkinatilanteisiin on sopeutunut paikallisia luonnonvaroja jalostava metsäteollisuus.

\footnotetext{
1 Maija Halonen, Researcher, Karelian Institute, University of Eastern Finland, P.O. Box 111, 80101 Joensuu, Finland; E-mail: maija.halonen@uef.fi

2 Juha Kotilainen, Professor, Department of Geographical and Historical Studies, University of Eastern Finland, P.O. Box 111, 80101 Joensuu, Finland; E-mail: juha.kotilainen@uef.fi

${ }^{3}$ Markku Tykkyläinen, Professor, Department of Geographical and Historical Studies, University of Eastern Finland, P.O. Box 111, 80101 Joensuu, Finland; E-mail: markku.tykkylainen@uef.fi

${ }^{4}$ Eero Vatanen, Researcher, Karelian Institute, University of Eastern Finland, P.O. Box 111, 80101 Joensuu, Finland; E-mail: eero.vatanen@uef.fi
} 


\section{Introduction}

As the central source of income and wealth, one common characteristic of small resource towns and their hinterlands is their reliance on resource-based production. Global demand maintains the cyclic growth and transformation of resource-based industries and relatively high rural populations in countries such as Finland. As labour productivity has increased, reducing above all the amount of work required in forests and mills, jobs in forestry first and then in the forest industries have diminished in Finland over the last five decades. Moreover, a wave of mine closures took place in the 1980s. For the resource towns and rural areas in Finland, the increase in labour productivity and closures of mills have led to high unemployment, reflecting the local formation of surplus labour and lack of opportunities for economic diversification.

The purpose of this article is to show how the resource-based industries and their production cycles have impacted on the development of Finnish resource towns by using the municipality of Lieksa as an example. As development in Lieksa seems to consist of episodes, development processes are conceptualized in terms of industry life cycles (Edenhoffer and Hayter, 2013; Peltoniemi, 2011; Potters and Watts, 2011). Generally, the factors behind the mechanisms of the industry life cycles of resource-based towns have been scrutinized in order to generalize resource-based local development. As an example of the sparsely populated Nordic pattern of development (Gløersen et al., 2005), the article illustrates changes in industrial activities, employment and population in a town in the remote peripheral region of North Karelia, Finland. The case study town is located in forested Fennoscandia, at the easternmost part of the European Union (EU), about 500 kilometres northeast of the capital city of Finland, Helsinki, and ca. 100 kilometres from the regional centre, Joensuu (Fig. 1).

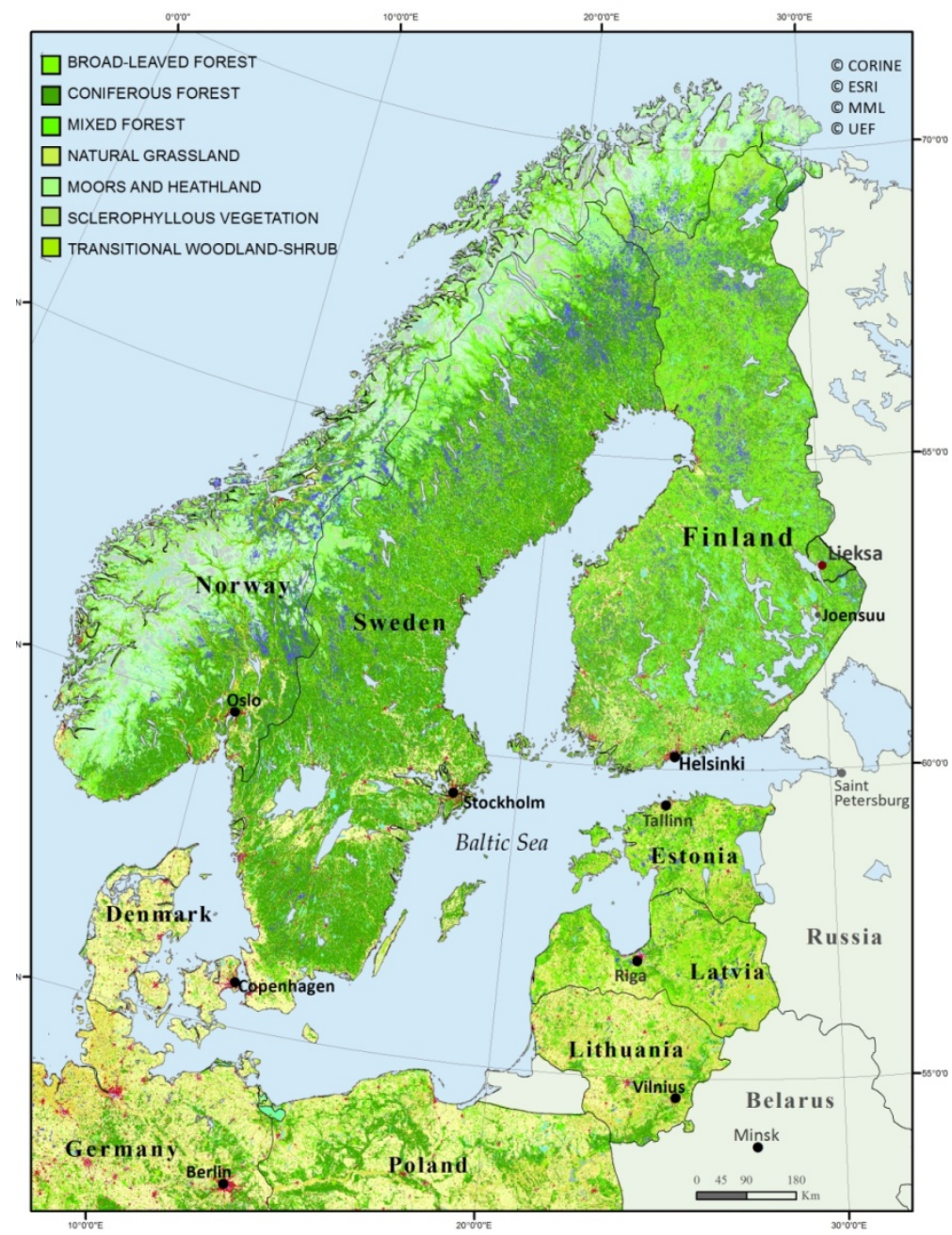

Fig 1. Lieksa in the forested northern periphery of the European Union. 
As a whole, the municipality covers $4,000 \mathrm{sq} \mathrm{km}$, with about $80 \%$ of its 12,000 inhabitants living at central core area $\left(62^{\circ} 19^{\prime} \mathrm{N}, 30^{\circ} 01^{\prime} \mathrm{E}\right)$; the rest consists of small villages, economic forests and wilderness. Due to its large hinterland, Lieksa is classified as a sparsely populated rural municipality (Malinen et al., 2006) and its average population density is merely 3.63 inhabitants per square kilometre (Official Statistics Finland, 2013a). The urban-rural structure of the municipality includes all spatial categories between the town centre and the extremely sparsely populated rural area (Helminen et al., 2012). The main urban centre of Lieksa (Fig. 2) fulfils all the criteria for a small town centre in Finland; for the last three years the average number of inhabitants has been over 5,000 , the urban population density is over 400 inhabitants per square kilometre, the amount of jobs is more than 2,000 and their areal density is high enough. The commuter belt of this town centre is more densely populated than the remote hinterland, but the businesses are more rural-like than in the centre with, for instance, active agricultural farms (Lieksa, 2012). Beyond the centre and the commuter belt a very sparsely populated area begins and is mainly covered by forests - the resource on which the economy of this town was based for more than a century.

The vicinity of the growing European timber market expanded the utilization of forest resources and increased the demand for local labour force at the beginning of the $20^{\text {th }}$ century (Aarnio, 1999, pp. 166-173), which accelerated population growth. Over the last century, the economic development of the town emulated the general development of rural Finland. The town activities expanded to marginal areas through the increased use of natural resources, herewith causing a peak in the number of labour force and population in the early 1960s (Fig. 3). In Finland, rural population growth was sustained and escalated as a corollary of the post-WWII settlement policy when 9.1 per cent of the land area was redistributed through the Land Acquisition Act to settlers in agriculture and forestry, but increasing even more the number of new one-family houses of non-agricultural settlers than those of farmers (Tykkyläinen, 1995, pp. 139-140). At first, the growing industries in small towns and rural areas offered new jobs for the growing populations. However, less than two decades later, the rural periphery faced a structural change and depopulation as the entering of the baby boom generation to the labour market simultaneously with the rationalization of primary production led to large scale migration from rural areas to cities in Finland and Sweden (Rannikko, 1999, pp. 215-217).

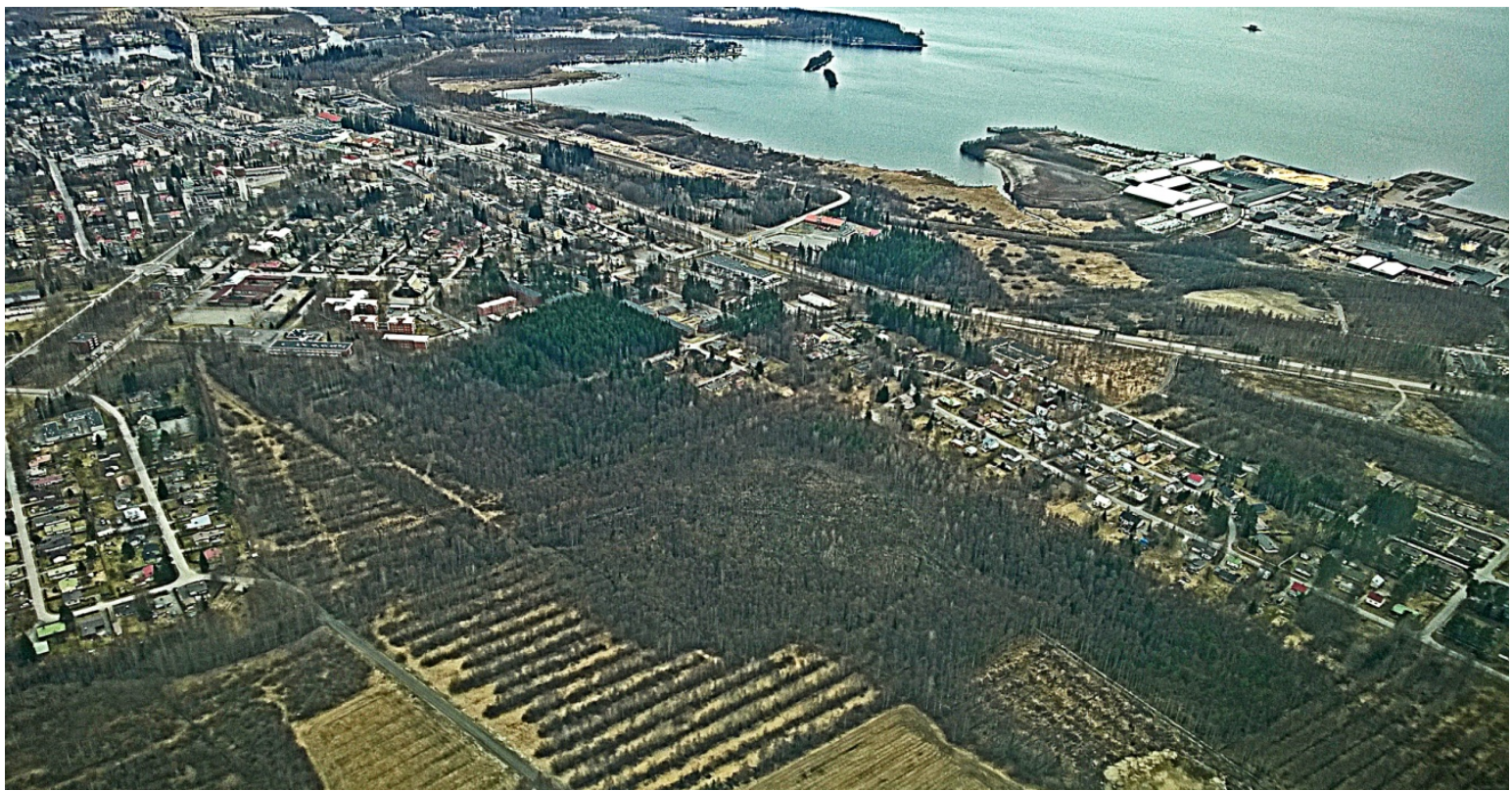

Fig 2. The centre of Lieksa viewed from the north in May 2014, including the Kevätniemi Saw Mill on the right upper corner (photo: M. Tykkyläinen).

The rate of urbanization and industrialization in Finland was record-breaking in European terms in the 1960s and the 1970s (Tervo, 2005, pp. 267). The rapid change from an agrarian society to an industrial society and further to a post-industrial society with the service industries dominating, was caused by changes in the economic conditions and political decisions, and 
resulted in the large scale migration (Virkkala, 1994, pp. 69-70). Lieksa lost about 7,000 inhabitants due to migration only in ten years (Fig. 4). The socioeconomic restructuring processes were mitigated by the establishment of spatially equal welfare services and decentralization of public tasks in the late 1960s and the 1970s. In parallel, regional policy funding was allocated to disadvantaged regions since 1966 (Moisio and Leppänen, 2007; Sippola 2010). The results of these policies were, however, insufficient for stopping the vicious circle of diminishing employment and population and the growing proportions of aging population in places such as Lieksa (Fig. 3; Fig. 4).

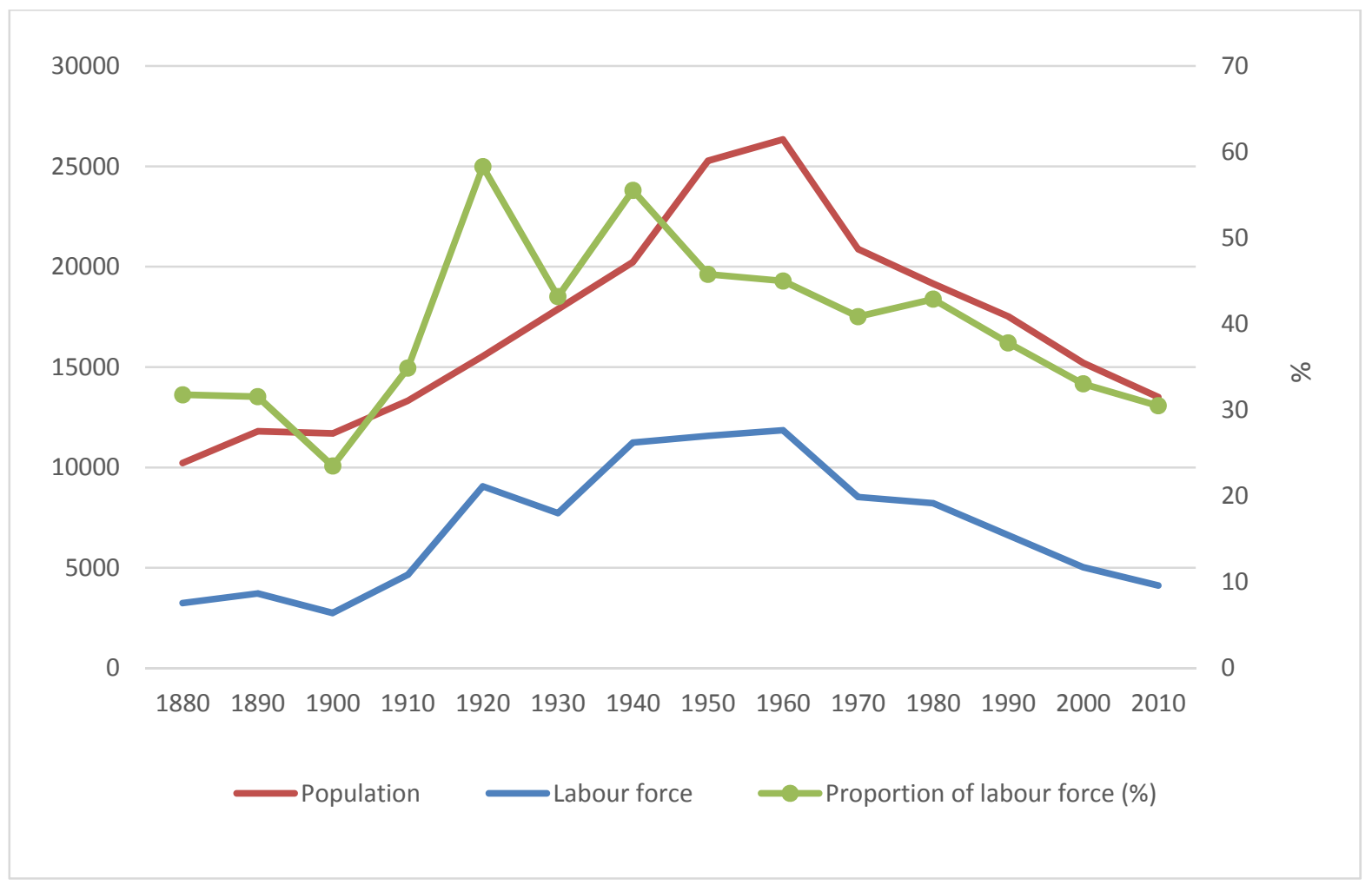

Fig 3. Population, labour force ${ }^{5}$ and the proportion of labour force to the total population (data sources: Official Statistics Finland, 1979; 2014a).

In what follows, the article will introduce the research perspective on primary production in resource regions that deals with the socio-economic dependence of regions and localities on the production of natural resources. The conceptual approach of resilience is drawn from for discussing the ways in which regions and localities can manage pressures to change due to changing larger scale economic conditions. The article will then explore the various phases of industry life cycles in the case study town of Lieksa, Finland, and analyse the causes for each phase of transformation in these cycles (see also Kotilainen et al. 2015). Finally, it will be discussed whether it is likely that another growth cycle will emerge.

\footnotetext{
${ }^{5}$ Labour force (economically active) is defined as comprising both employed and unemployed people (Official Statistics Finland, 2015a).
} 


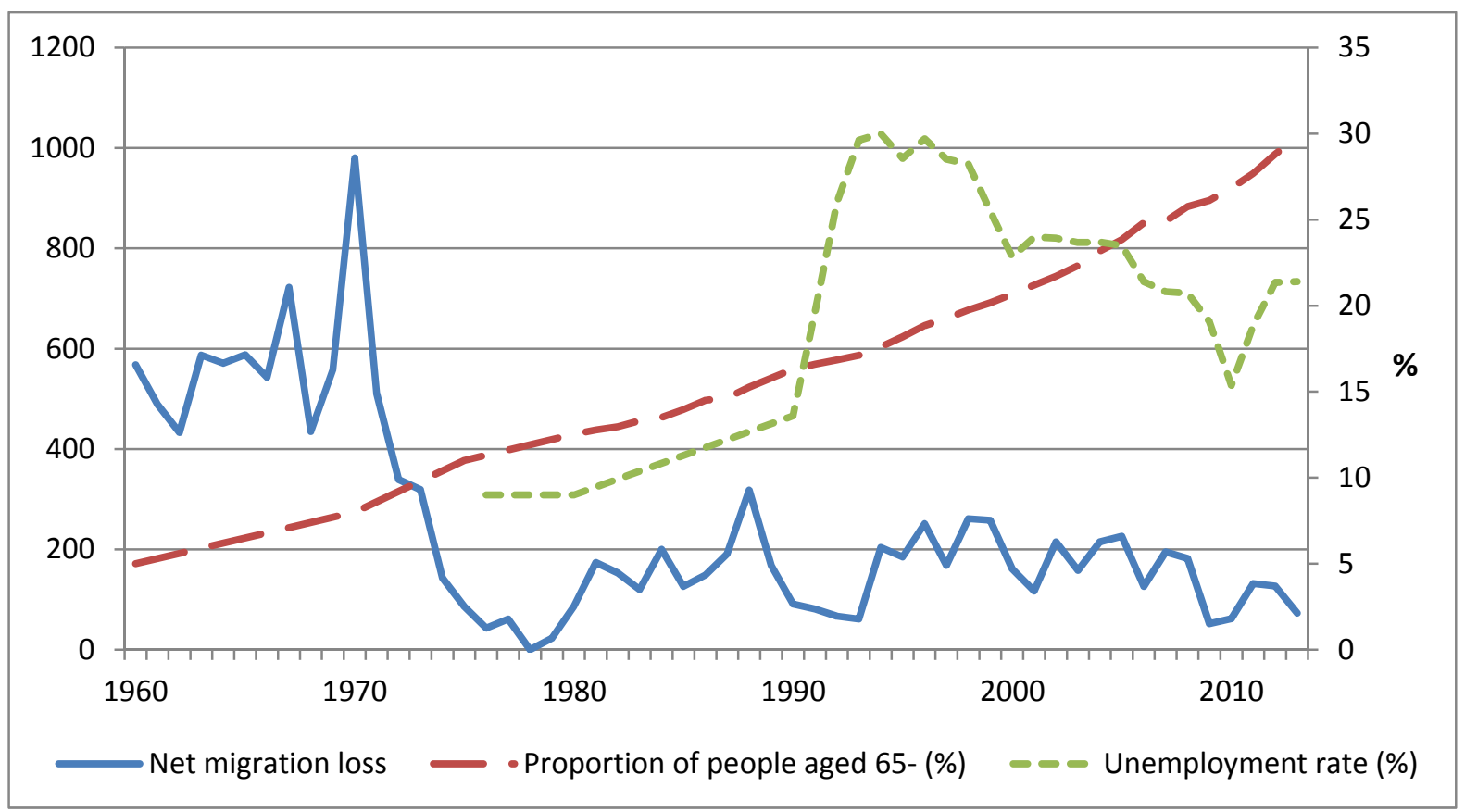

Fig 4. Annual net migration ${ }^{6}$ loss, the proportion of people aged 65 and over $^{7}$ to the total population, and unemployment rate ${ }^{8}$ (\%) (data sources: Lieksa, 1980; Official Statistics Finland, 1960-1986; 1982; 1990; 2014a; 2014b; 2014c).

\section{Dependence on primary production, resource cycles and geographical conditions}

\section{Changing spatial patterns of wealth}

The current rural decline in the forested parts of Finland is primarily the outcome of productivity growth. The findings in earlier studies in Canada have often revealed the regressive impacts of forestry dominance, primarily due to dependence on logging, on economic well-being, including high poverty rates and unemployment (Freudenburg and Gramling, 1994; Overdevest and Green, 1995; Patriquin et al., 2007; Stedman et al., 2004; 2005). Leake et al. (2006), for instance, found that forest dependence in Canadian communities had a significant positive correlation with the unemployment rate and an increase in the poverty of households over the period 1986 - 1996. In Finland, resource towns, such as the towns of forest industries and mining industries, have been wealthy and the outcome of restructuring has been a relative decline of well-being compared with the surrounding areas of the towns (Lehtonen and Tykkyläinen, 2010a).

Competitiveness in mill towns and rural areas generally comprises assets such as abundant natural resources, access to non-urban resources, cheap land, place commitment and natural amenities (Markey et al., 2006). Physical properties of given areas, such as climate, soil and accessibility, impact economic performance and wealth (Gallup et al., 1999; Sachs and Warner, 1997a; 1997b). In post-industrial economies, the legacy of resource dependence is a reason for a decline in jobs in hinterlands since value-added increasingly comes from high order services (Gløersen et al., 2005, pp. 155-159). The barriers to economic diversification include a stagnant economic base, a low level of education, an ageing and declining population and declining employment. Many elements of competitiveness demanded by new, growing industries are

\footnotetext{
${ }^{6}$ Intermunicipal net migration is the difference between intermunicipal in-migration and intermunicipal out-migration (Official Statistics Finland, 2015b).

${ }^{7}$ According to demographic dependency ratio people aged 65 and over are calculated as elderly persons (Official Statistics Finland, 2009).

${ }^{8}$ Unemployment rate is the proportion of the unemployed people to the active population (labour force) (Official Statistic Finland, 2015c).
} 
poorly developed in rural settings (Kitson et al., 2004; Mikkonen, 2002). At a time when growth in jobs is concentrated in the largest cities, geographically marginal regions suffer the most in Europe as a result of their declining industries and more problematic locations (Espon Project 2.1.3, 2006). In Finland, economic growth and restructuring, especially in robust urban areas and their adjacent rural areas, have attracted labour from less productive sectors and areas (Tervo, 2009). At the regional level, the transformation to a knowledge economy, which is urban-centric, is most problematic in remote rural areas, which are heavily dependent on inadequate regional assets and human skills (Kangasharju and Pekkala, 2004). Similarly, rural areas close to the largest cities in Canada have succeeded better than other rural areas in compensating for employment losses in the primary industries, as they have benefited from commuting to the regional cores (Partridge et al., 2007; Polèse and Shearmur, 2004). Economic wealth occurs unevenly geographically as a result of stagnant or declining demand and poor competiveness for economic diversification.

Growth in current global demand increasingly consists of manufactured consumer goods and services. In such economic circumstances economic growth tends to constitute a series of cumulative, spatially centripetal processes generated by economies of scale and a relative decline in transportation costs. Since production shifts relatively away from primary production and attached industries, place-bound initial advantages, such as hub location and knowledge (Fujita and Krugman, 2004, pp. 145, 147; Krugman, 1991; 1993; 1998), are crucial for restructuring and growth. According to Krugman (1993), there is a strong accidental component in the upsurge of development. Increasingly some of the initial advantages, such as the concentration of human capital, emerge as a result of the policy measures of a constructed advantage (Cooke and Leydesdorff, 2006). Subsidies to investments and training, growth centre policy and the promoting of research and development related to the industry shape the economic landscape. Suorsa (2007) and Gløersen et al. (2005) concluded that the measures of recent policies do not reach Finnish peripheral regions and even decrease their opportunities.

The bicentenary economic history of the municipality of Lieksa has rested on the utilization of ores, forests and land for farming when its spatial dynamics have comprised phases of colonization and population concentration. Similarly with other resource-based areas, Lieksa is strongly dependent on the global market. Mills have been part of global production chains and networks and hence a suitable location and the emergence of costs must be interpreted in relation to particular networks of their time (Garretsen and Martin, 2010; Kortelainen and Rannikko, 2014). Moreover, current growth in the boreal zone takes place outside the primary and traditional manufacturing sectors; an increasing part of value-added is generated by the service sector and the production of information in production systems. In many resourcebased regions, the economy evolves in spatially uneven ways which indicates a changing demand and relative cost conditions globally in local industries impacting finally on factor compensations (wages, salaries, profits and rents) and local living conditions. The poor generation of wealth in forested areas in the current phase of industrial development in the boreal zone tends to be a result of industry life cycles in their rationalization phase as can be seen from this case study as well.

\section{Resilience, adaptive capacity and reactions to pressures to change}

Resource cycles (Hayter and Patchell, 2011), and more broadly, industry life cycles can be understood by drawing from discussions on the economic, social and environmental resilience of natural resource dependent communities (Wilson, 2012). The life cycle of an industry is a result of the evolution of the economy when new technologies and shifts in consumption patterns create the series of the emergence and disappearance of industrial activities and adaptation processes in production systems (Brezis and Krugman, 1997). These evolutionary processes consist of the stages of growth, decline or shake-out and adaptation. Especially the last one is made possible by adaptive capacity which is related to the potential for resilience.

Resilience is a concept that originates in the physical sciences; it has become popular in research seeking to understand human-environment interactions (Adger, 2000; Folke, 2006), and has increasingly been stretched to cover analyses in the social and regional sciences and 
economic geography (Christopherson et al., 2010; Martin, 2012; Myant and Drahokoupil, 2012). An underlying aim has been to introduce a conceptual, if not a substantial, analogy between these very different disciplines. In short, resilience can be seen as a notion that refers to the ability of a system or region to cope with change. Resilience is very much a notion related to systemic thinking and, in essence, there is an assumption about a physical or social system that faces disruption it has to cope with in one way or another. Usually these distractions have been seen as abrupt, but also slower processes can be seen to cause a threat to a system's resilience. The notion of resilience has been given different connotations, starting from the perhaps best-known interpretation that resilience is about a system's ability to resist change. However, resilience has also been taken to mean a system's capability to adapt and change enough to be able to cope with a new situation, as well as its learning capabilities (Folke, 2006). One reasonable definition refers to a system's ability to maintain its essential elements, such as population, by changing its non-essential elements, such as industrial structures (Manyena, 2006).

Resilience can also be a normative concept, with the idea that the more resilient the socialecological system is the better, and resilience should be promoted by social action (Walker and Salt, 2006). However, resilience should not be seen only as a positive ideal. It could easily be thought of systems connecting the political, the economic and the ecological, the resilience of which may not be seen as a goal by many; on the contrary, the decrease of resilience keeping that system going may have been the aim of many actors. For example, one such system could consist of the maintenance of extraction and utilization of fossil resources for producing energy instead of developing renewable energy. Nevertheless, if the problems of regional development and regions that are facing economic shocks are considered, it is easy to see the resilience of a region or a locality as something worth striving for. Resilience, in such a case, could be seen as social and economic capacity ensuring the region's or locality's possibilities to maintain development and well-being. In the Nordic countries, governmental regulation with regional policy and the Nordic welfare regime have been in central role in local adaptation. Thus, local adaptive capacity and governmental regional and welfare policies are intertwined. In research, this issue of whether resilience is positive or negative and from whose perspective needs to be addressed. An option is just to try to see the occurrences during which a social-ecological system has demonstrated its resilience.

It is a basic argument in the literature that systems at various scales are interlinked, and a disruption in a system at one scale is usually likely to cause disruptions in related systems on larger or smaller scales (Folke, 2006). Often the resilience of systems at different scales may be in contradiction, and the resilience of a system at one scale (e.g. global) may even prevent the resilience of another system at another scale (e.g. local). Moreover, there may be certain types of regions or localities where resilience as a capacity to withstand changing economic conditions may not have emerged. Given these scalar complexities, in order to proceed with a concrete analysis of regional or local resilience, it looks like a wise strategy to delineate empirical analysis in some cases and focus, for example, on a specific community and explore what components might constitute resilience there.

As noted, resilience has been given several meanings, and Martin (2012) has explored the notion of resilience in its various forms for the purpose of an analysis of regional economies. There are several options for a region to react to economic pressures. Of these, engineering resilience would be the rebound of a region back to its previous state. The concept of ecological resilience resonates with the idea of regional economic hysteresis, where the regional economy finds its previous growth trend but from a different starting point. Adaptive resilience, in turn, would lead to realignment of the constituents of the regional economy. Martin (ibid.) then identifies four different ways for a region to react to a state of economic shock: 1) resistance, or the degree of sensitivity or depth of reaction of a regional economy to a recessionary shock; 2) recovery, the speed and degree of recovery of a regional economy; 3 ) reorientation, the extent of adaptation of a regional economy in response to a recessionary shock; and 4) renewal, or the extent to which a regional economy renews its pre-recession growth path or shifts to a new growth trend. In empirical analysis, the task could be to identify these different forms of resilience existing in different situations. Interesting as such an investigation could be, the kind 
of analysis that seeks to identify resilience in these different forms leaves open the question of how resilience emerges and how it could be promoted in a regional economy. Investigating the dynamics and components of resilience, therefore, remains a task.

Within this framework, adaptive capacity or adaptability can be taken to mean the ability of a system consisting of local actors and governmental actors with their regional representatives to prepare for stresses and changes in advance or adjust and respond to the effects caused by exogenous or endogenous processes. Increasing adaptive capacity improves the opportunity of a system - e.g. a community - to manage the varying ranges and magnitudes of adverse impacts, while allowing for flexibility to rework approaches if deemed at a later date to be on an undesirable trajectory (Engle, 2011). It is useful to see adaptability in a sense that the actors and institutions from the local level to the governmental level try to prognosticate the stresses and pressures for transformations in advance, thereby seeking to create the procedures of planned adaptation.

\section{Resource cycles and industry life cycles in Lieksa}

\section{Local natural resources as a basis}

Six cycles of industrial growth and decline can be identified in Lieksa. Some of them, especially those in the early stages, could be called resource cycles, as they were directly related to the voluminous utilization of local natural resources. When transport was expensive, ore and wood resources were locally deployed so that they were processed within the boundaries of the present-day municipality and then transported to other places for further processing or as intermediate products. The central competitive advantage was based on typical Weberian weight-loss industries, where raw materials are more expensive to transport than the finished goods. These cycles were long, and under structural adjustments that included war periods, industrial assets were reallocated to new or modified production. Agriculture and forestry employed the workforce especially in the earlier stages of economic development when production was more labour-intensive and less mechanized than it is today (Fig. 5).

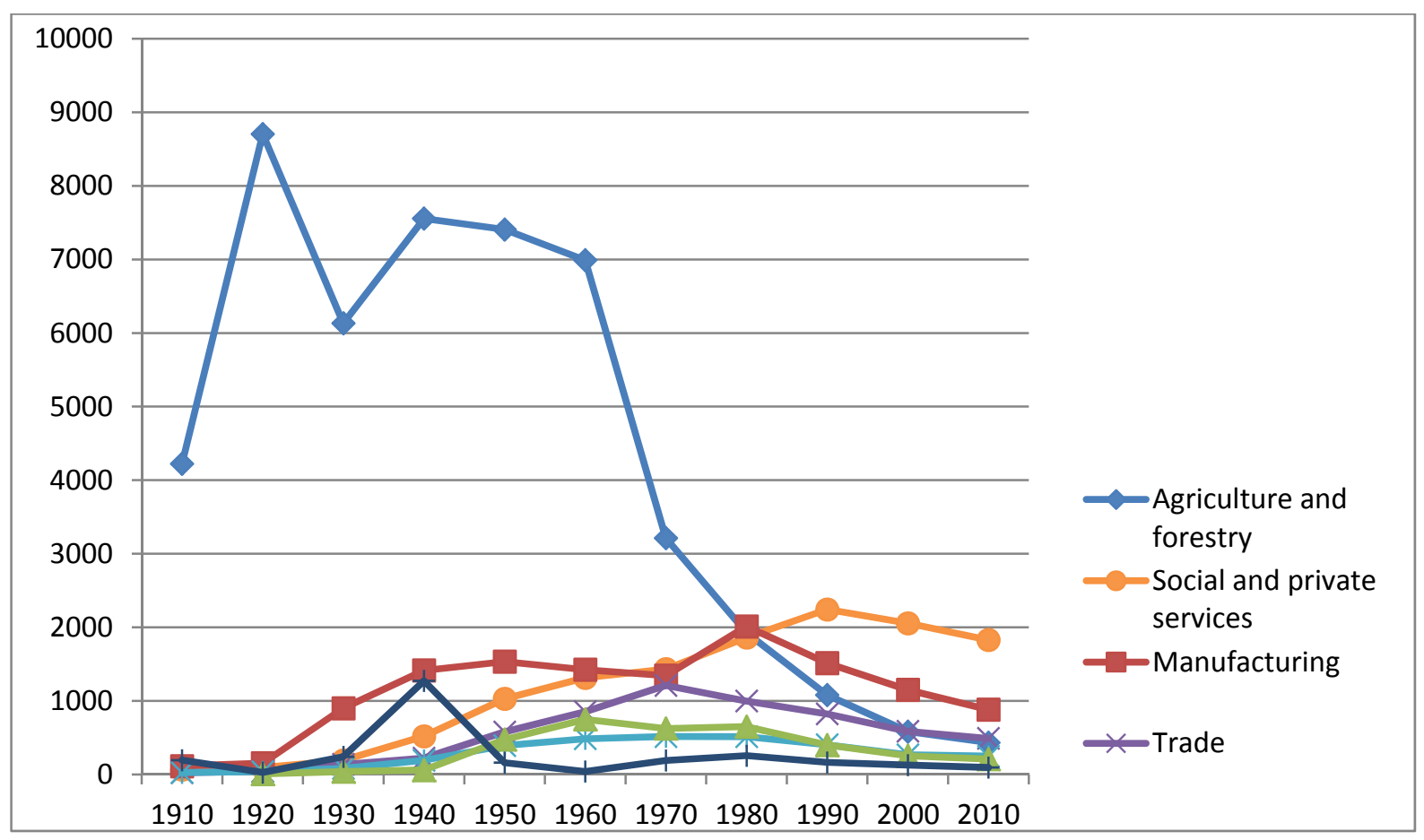

Fig 5. The employment ${ }^{9}$ impact of the resource cycles from the second cycle of agriculture and forestry ${ }^{10}$ to the fifth life cycle of the service sector in Lieksa (data sources: Official Statistics Finland 1979; 2013b).

\footnotetext{
${ }^{9}$ Employment covers all persons - both employees and self-employed - engaged in some productive activity (Official Statistics Finland, 2015d).
} 
In the later stage and in subsequent much shorter cycles starting from the early 1970s, manufacturing was not that much directly dependent on the supply of local natural resources any more. The utilization of local natural resources was not a key aspect for the emergence of manufacturing industries, as raw materials were easily imported. The growth in services and bioenergy has largely been the outcome of the increase of public spending. Nevertheless, while the importance of a natural resource waned, human labour resources prevailed as an important asset for resilience, as unemployment created abundant available labour force and a significant political motivation for generating any economic activities in the locality.

Transition from cycle to cycle reveals phases of resilience where the local economy attempts to recover from an economic shock often related to the increase of production costs or decrease in demand for the products for which the local resources are used. In this context, the emphasis is on the causes for the appearance and decline of each of the cycles. While more emphasis is placed on the occurrences in recent decades, it is explanatory to look back at the era of the origins of transformations that led to the continuous decade-long population decline still underway today.

The first resource cycle in the industrial era was based on lake ore (Oinonen-Edén, 1991, pp. 125). It lasted in a significant scale from 1829 - 1903. While Figures 3 and 5 fail to depict the population and employment impacts of the resource cycle of lake iron ore production that constituted the first phase of industrialism in Lieksa during the $19^{\text {th }}$ century, the surge in employment in blue in Figure 5 for the early decades of the $20^{\text {th }}$ century, impressive in its pace, shows the impact of state-led colonization measures. This second resource cycle is simultaneous with strong growth in the size of the population (Fig. 3). It was partly a result of a series of colonization phases from 1918 to the early 1960s, together with agricultural and industrial policies aiming to increase farming and forest work (Kupiainen, 1995; Rannikko, 2014, pp. 198-201; Saarelainen, 1995) and utilise forest resources by establishing saw mills and groundwood pulp and cardboard production (Kotilainen and Rytteri, 2011; Sippola, 2010). Employment in this second cycle surged at first as a result of the colonization laws in the 1920s aimed at social resettlement after the civil war, peaked in 1940, and then was maintained because of the post-WWII colonization policy until the 1960s (Fig. 5). Employment dramatically dropped in the 1960s as a result of mechanization in forestry. Changes in agricultural policy in the late 1960s led to a decline in small-scale farming; while colonization ended, the focus shifted to improvements of productivity in farming. Job losses in the primary sectors since the 1960s were only meagrely compensated for by an increase in employment in manufacturing (Fig. 5).

The first rise of forest mills (in the third cycle) since the 1920s was a result of nation-scale industrialization policies concerning the forestry sector as an important basis for the national economy (Kotilainen and Rytteri, 2011). Already after political separation from Russia and its consumer markets through independence in 1917, exports from Finland had oriented to western markets and became even more raw materials intensive (Hjerppe, 1989). The importance of local raw materials, especially timber, increased. In Lieksa, this third long industry life cycle starting in 1903 is shown in the evolution of cardboard and plank production peaking from the 1960s to the 1980s (Fig. 6). Employment then came down as a result of the renewing of factories to be more cost-efficient. This meant, in practise, that expensive labour was substituted by modernized machines in the early 1980 s.

\footnotetext{
10 The Finnish statistical system aggregates agriculture and forestry, so separating them is not easy on an exact level; however, the assumptions in the article are made on the basis of known developments within these sectors. It is also assumed that the agricultural and forestry employment in 1910 has been underestimated and in 1920 overestimated in the original statistical data due to the changes of classification.
} 


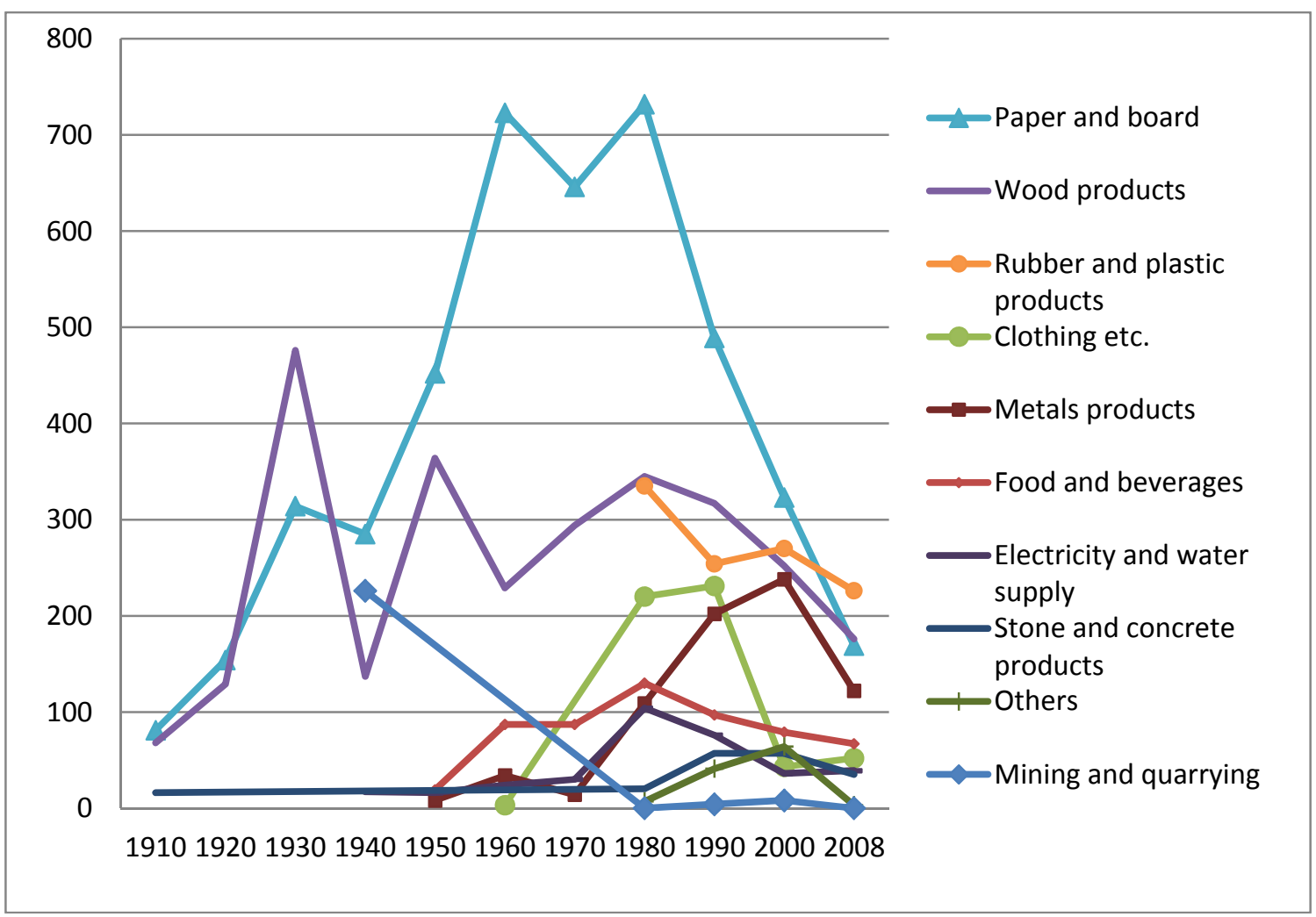

Fig 6. Development of employment in manufacturing and mining (data sources: Regional Council of North Karelia, 2009; Vatanen, 1986).

Figure 7 exemplifies the internal transformation process of the third cycle through the ownerships changes of the major forest mills, which have come across several changes during its existence, especially in the last 20 years. The first major turn took place in the early $20^{\text {th }}$ century, at the time when the interest towards paper and pulp production was raised and hereby the major forest companies, such as the Finnish Ahlstrom and the Norwegian Gutzeit, became attracted by the local mills and the forest resources nearby (Kuisma 2006, pp. 369382). The iron ore producers commenced to invest in wood processing industries leading to the first demerger when the sawmill producing planks in Kevätniemi diverged from the Pankakoski Groundwood Mill producing groundwood pulp and cardboard (Fig. 7).

The era of state ownership began in 1909 when the state forest administration (Metsähallitus) began its operations at the Kevätniemi Saw Mill for the purposes of the construction of the railways (Palokas, 2002). Later on, as the Norwegian Gutzeit lost its interest for the operation in the unstable country after the civil war and as the state of Finland had willingness to increase its proportion at the market, the Pankakoski Groundwood Mill became as a part of the majority state-owned Enso-Gutzeit: at first as a separate unit and then as a merged unit of the parent company (Hoving, 1961; Näsi et al., 2001). For the next six decades the ownership stayed immutable until the factory producing packaging boxes, established after the WWII, was sold to Ahlstrom in 1987. At this time, the production line was converted along with new machinery to produce also plastic-based products (Kontiainen, 2010; Luoma-aho and Strömberg, 2008), thereby shifting towards the import of raw materials and more place-neutral manufacturing and diverging from the main operations of the board mill.

In the mid 1990s, a new phase began for the Finnish forestry companies since they introduced the aim of internalization in their strategies and became more integrated in the global competition through supranational mergers and acquisitions (Sajasalo, 2003, pp. 165-173). Simultaneously Pankakoski Groundwood Mill faced major transformations in ownership linked to the production of boards for packaging and graphical end uses based on local natural resources and imported raw materials: at first merging with other Nordic businesses and then with more globally oriented investors through acquisition (Fig. 7). 
PANKAKOSKI MILL

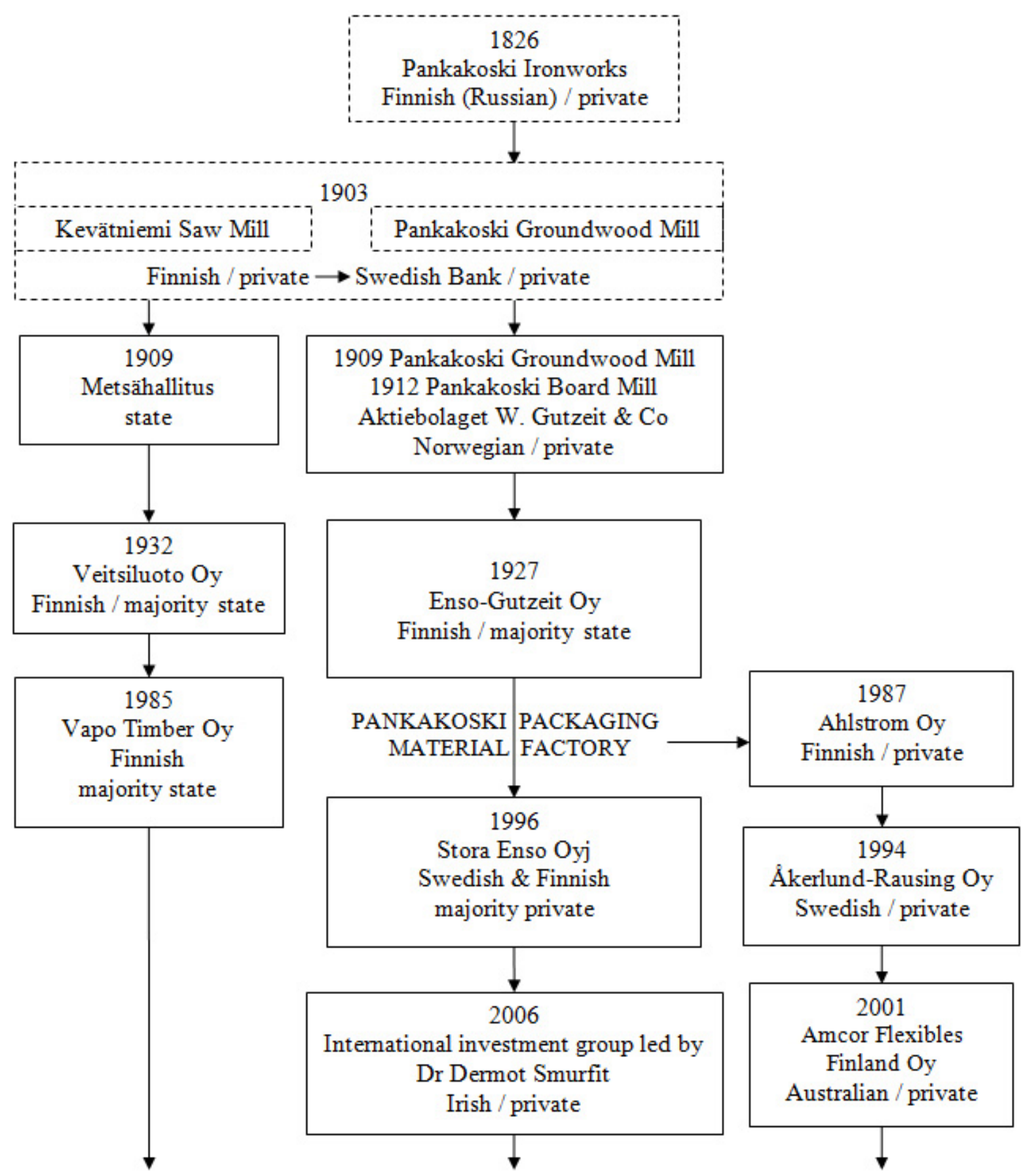

Fig 7. The ownerships of the Kevätniemi Saw Mill, the Pankakoski Board Mill and the Pankakoski Packaging Material Factory (data sources: Kontiainen, 2010; Luoma-aho and Strömberg, 2008; Oinonen-Edén, 1991; Palokas, 2002; Pankaboard, 2013; PRH, 2014; Pääkkönen, 2013; Stora Enso Oyj, 2014).

\section{From local natural resources towards a diversified economy}

The upsurge in light manufacturing, the fourth industry life cycle, took place as a reaction to job loss in the local economy where primary production improved its productivity dramatically after the late 1960s. A new, large post-war generation simultaneously entered the labour market. As a mixture of local and national policy measures, an industrial estate was established in Lieksa (Vuorenmaa, 2003). This was a result of a set of governmental regional development policy measures that were at their height in the 1970s (Sippola, 2010). Foreign trade was deregulated in the same two decades. Finland became an associate member in EFTA in 1961, made a free trade agreement with EEC in 1973 and signed a special agreement with SEV (Comecon) 
countries in the 1970s. Moreover, the Finnish mark was devaluated in 1967 strongly which generated together with the opening of the European markets favourable conditions for diversification of industrial structures. Lieksa was one of the first municipalities in the country to benefit from the industrial estate instrument (ibid.). At this point, it was no longer local natural resources that were sought to be utilised but, instead, the new industries used imported raw materials. For instance, clothing factories and metal products workshops were established, and the rubber industry started its production on a large scale (Fig. 6). There was, however, still a relatively abundant labour force that was struggling with problems of unemployment.

What were the prerequisites for these investments in the 1970s? First, plenty of labour was available as a large generation entered the labour market and employment in the primary sector declined sharply. Second, local industrial culture in the community gave competitive advantage in relation to other, more rural, Finnish municipalities. Third, regional policy instruments enabled the attainment of financial support from the government for investments, research and development, the training of labour and wages for a few years after the enterprise was founded, and loans were available from KERA/Finvera, a state-owned regional development fund, that lent money and provided financial capital to improve the economic progress of underdeveloped regions (Tykkyläinen, 1992; Yli-Jokipii and Koski, 1995). As a result, Lieksa's economy became consciously diversified in the 1970s. It could be assumed that this diversification should have led to a situation in which the local economy was less vulnerable to disturbances, as it was no more that dependent on a single resource or a single line of production. Interestingly, this was not the case. After ten years of relative success brought by incoming investments by companies and the national government, a sharp decline in manufacturing jobs began in the 1980s and is still continuing (Fig. 6).

How can this turn to a decline be explained? First, the diversification of the local industry was based on imported raw materials and other inputs and thus this manufacturing has been easy to relocate when relative competitiveness declined. Second, deindustrialization prevailed in Finland in the 1980s, and these new industries in the marginal areas became vulnerable as regional policy supports gradually vanished after the infant period. Third, the prices of many products manufactured by the industries in Lieksa were high for the domestic market and could not compete with imported products. Fourth, many companies had to adapt to a situation where governmental support shifted from traditional labour-intensive manufacturing towards funding for technology-driven development. In this industrial climate, the more traditional industries in Lieksa had to improve their cost-efficiency which led to redundancies and even shrinking turnovers. The conditions of development became disadvantageous to remote localities such as Lieksa. An increasing part of the blue-collar manufacturing activities in high-cost peripheries found themselves on the losing side of the spatial margin of profitability (Hayter and Patchell, 2011, pp. 249; Smith, 1981, pp. 111-116).

However, the industry life cycles in Lieksa since the 1970s and the resilience of the local economy have not rested on a growth in manufacturing industries only. The cycle of the municipal service sector, as the fifth cycle, peaked at the beginning of the 1990s. As illustrated by Figures 5 and 8, employment grew continuously in the service sector from the 1920s until around 1990. Until the mid-1960s, colonization and the expansion of the primary sector and the forest industries increased the demand for services as population grew. After that, much of the increase in employment in services can be explained by the construction of the Nordic model welfare state, where public health care and social services were to be provided evenly across the country. The era of the intensive construction of the welfare state began in the early 1970s, and the idea was to create municipal local services that were administrated, produced and financed by the municipalities, but additional financial government support was provided on demand (Kortelainen, 2010). In Lieksa, this reform produced a considerable need for educated employees, especially in the health care sector, and without the simultaneously created system of state subsidies, these wide-ranging reforms would not have been possible (Lieksa, 1975; 1976). As Figure 8 shows, the expansion of the public sector also continued in the Pielinen Karelia sub-region, to which Lieksa belongs, until the late 1980s. However, compared with the decline of employment by more than 5,000 during about two decades, the increase in jobs in the service sector was only about 1,000 jobs and in 
manufacturing even less. Hence, adaptive capacity, although supported by regional policy and the expansion of the welfare state, was not sufficient as the overlapping growth cycles in the service sector and manufacturing could not bring about enough resilience to prevent continuing population loss. Industrial renewal and a shift to a new growth trend with the support of regional policy failed in the long run and the service sector had very limited possibilities to expand as local demand was not sufficient. These state policies were not based on any initial advantage, such as natural resources, or a long-term competitive advantage, such as R\&D. The disadvantages brought about by the attributes of the peripheral location finally defeated a great deal of constructed advantage, that is, the industrial estate and regional policy support.

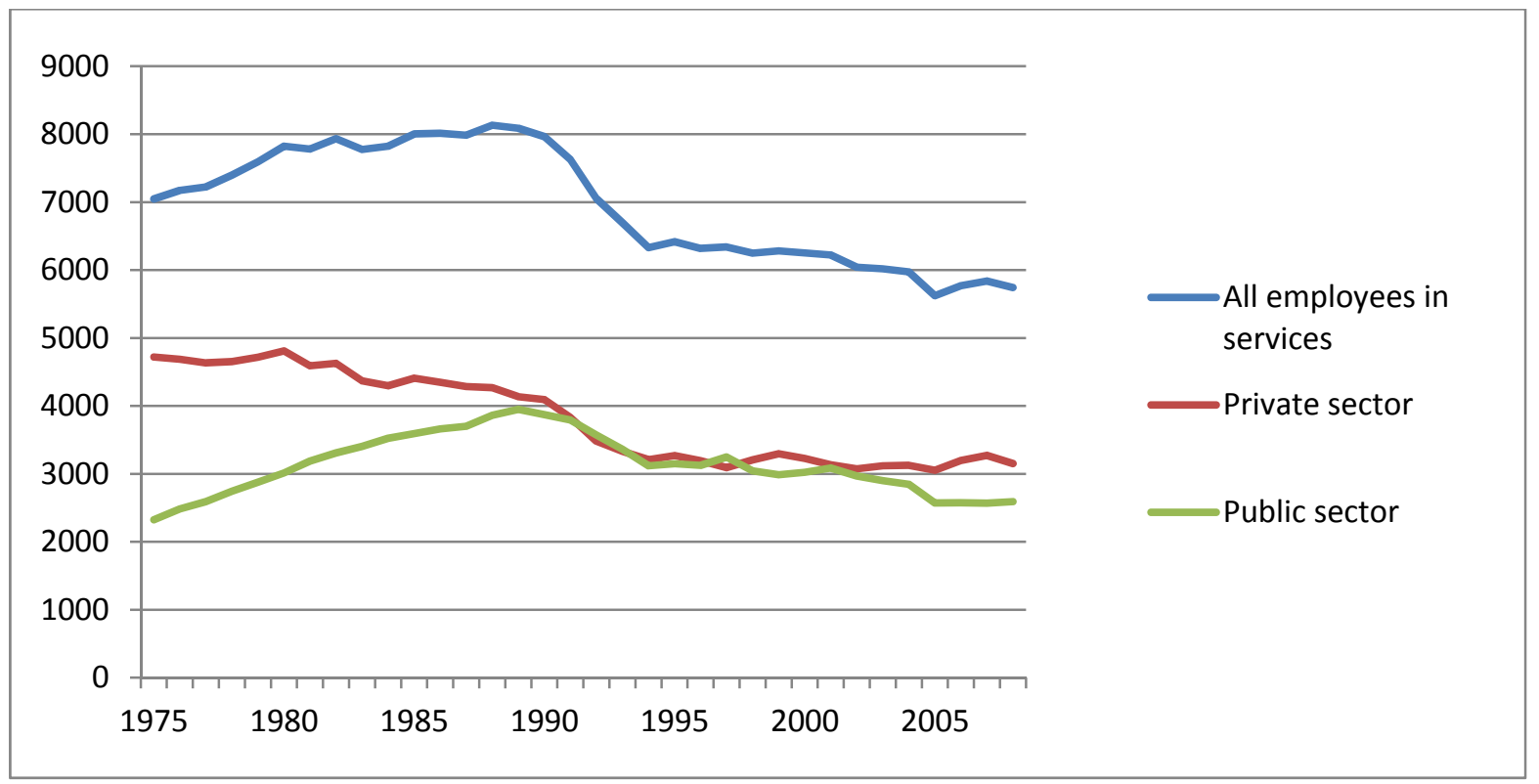

Fig 8. Employment changes in the private and public service sectors in the district of Pielinen Karelia (includes the municipalities of Lieksa, Nurmes, Juuka and Valtimo), 1975-2008 (data source: Official Statistics Finland, 2014d).

Overall, the driving forces since the mid-1960s for the increase in employment outside farming and forestry were a combination of global and domestic demand for consumer goods, the measures of national scale policies and high supply of labour. Much of the manufacturing work was based on assembling work and, therefore, the shift to the global spatial division of labour along with trade liberalization had a significant restructuring impact on the local manufacturing sector. Much of its competiveness decreased in relative terms.

The balance between competitive factors in different spatial scales has shifted over time. The attractiveness of local natural and human resources and governmental interventions in addition to market demand were crucial in generating booms and resilience in the sense of reorientation in the early long cycles. In the case of the industrial estate, local attractiveness rested on subsidized human resources trained for factory work, investments grants and R\&D grants, and local natural resources had only a minor role. Similarly, in the case of increasing services, local natural resources as inputs played a minor role as only a fraction of growth came from tourism, although the introduction of nature tourism services has increased the importance of landscape as a local resource.

\section{Structural adjustment of manufacturing and the service sector from the 1990s on}

Lieksa came to a turning point at the turn of the 1990s (Fig. 9). Since then, there has been no employment growth in the main industries. The downtrend of the local economy, except the service sector, already began before the 1990s (Fig. 5). In the most of the branches of industries there was no abrupt collapse, but a steady ongoing trend of reduction in employment. Several simultaneous disturbances deepened the job loss further. One of the most unfavourable processes was the nationwide recession in the early 1990s, caused by the chain effects of several factors which were mainly started by excessive foreign indebtedness combined with 
simultaneous devaluation; it eventually led to a plunge of demand in the domestic market and cuttings of public spending (Kiander, 2001, pp. 36-39). At the same time exports to the Soviet market came to an end. The unemployment rate in Lieksa surged to 30 per cent (Fig. 4).

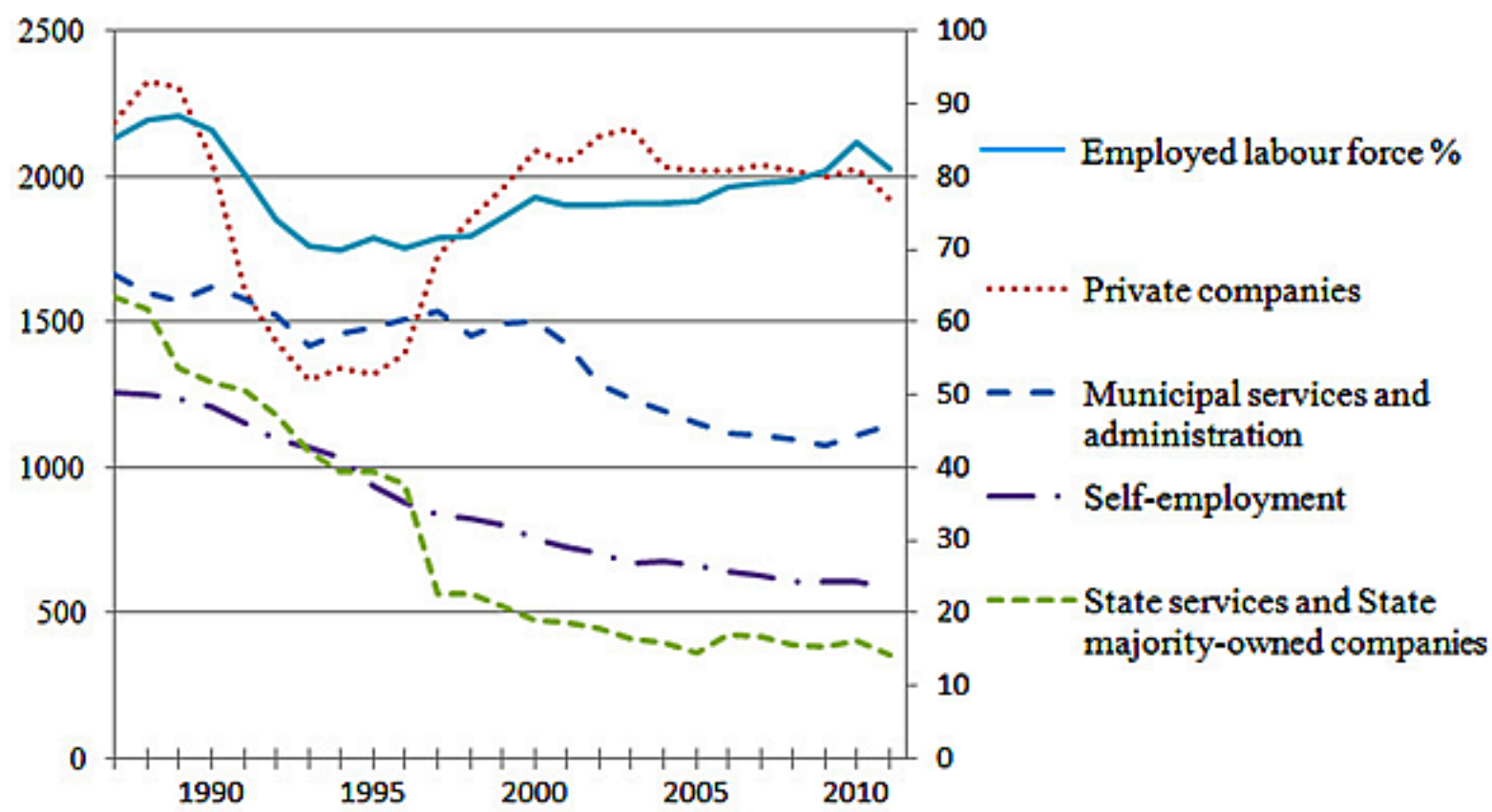

Fig 9. Employment change by the sector of employer (number of employees) and employed labour force (as per cent of total labour force) (data sources: Official Statistics Finland, 2013b; 2014a).

At this turmoil, governmental support for the services of the welfare state and for regional policy measures was reappraised. The reduction of public spending was partially an outcome of the economic recession, but also the time was favourable for a policy change from nationally regulated social equity-oriented goals towards an internationally-oriented capitalist society regime (Julkunen, 1992, pp. 13-15; Julkunen, 2001, pp. 72-80). The political aspirations of that time as well as the accession of Finland to the European Union in 1995 stressed the strengths of specialized and competitive regions in regional policy instead of aiming at abolishing the disadvantages of developing areas (Kortelainen, 2010, pp. 353-356). New EU policies and funding mechanisms such as regional structural funds and LEADER-funding for rural areas reformed and replaced the former regional policy in part (Danson and de Souza 2012; Eskelinen, 2001). The ideology of regional development shifted from the nationally governed top-down format into the combination of integrated programs regulated by the EU and regionally based bottom-up development projects (Malinen, 1998). The post-1995 development shows that even the newest development policy instruments have had only meagre impacts on development; Finland's membership in the European Union brought about new regional and local policy instruments, but they have not significantly created new jobs during the last 20 years.

Several changes in the global economy affected Lieksa. Due to changes since the early 1990 s, such as the collapse of the economy of the Soviet Union, the opening up of China to the world economy and its low labour costs, and the advance of the Latin American forest sector, it has been hard to maintain production in this relatively remote part of Europe. In retrospect, the industrial estate instrument could be criticised for its emphasis on imported raw materials and low-skilled, low-paid jobs, as it became far too easy to shift production to places with much lower labour costs in the 1990s.

A closer examination reveals how many of the changes in the upper institutional scales and the tighter links with the global economy have impacted on the local industry life cycles, and especially on the dissolution of public employment through the vulnerability of place-neutral manufacturing. The early 1990s recession first hit most severely in the private sector, but the decline in employment seems to have been more persistent and long-standing in the non- 
private sector (Fig. 9). The private sector lost almost half of its employment from 1989 to 1993, but it nearly managed to gain back the lost jobs by the year 2000. However, this job loss revealed by the statistics was caused by changes in company ownerships and simultaneous lay-offs in state majority-owned companies. The changes of ownership are reflected in part by the shifts of jobs from the public sector to the private sector. For instance, between the years 1996 and 1997 the national government decided to diminish shares in Enso Oyj, the predecessor of Stora Enso Oyj, which changed the company's employment classification from the state-based to private-based employment class (Enso Oyj, 1997). Moreover, in Lieksa over 300 employees of the local cardboard company changed over from the public to the private sector (Pankakoski Board Mill, 1996; Fig. 7).

Since the early 1990s, first the state sector and later the municipal sector started to rationalize the welfare system (Fig. 5; Fig. 9) that pushed down employment in the whole service sector. Productivity increase and the shifting of political interest to the southern part of Finland continued during the next decade. The Finnish Border Guard closed down two of its border guard stations by the end of the 2010 (Finnish Border Guard, 2010), which had an impact in the border town of Lieksa. In addition, the cutbacks in the state-owned forest administration (Metsähallitus) reduced employment in the primary sector. The diminished number of the active farms - from 542 to 191 between 1990 and 2010 (Tike, 2013) - pushed down especially the number of self-employed persons (Fig. 9).

Similarly to the service sector, developments in manufacturing differed by industry (Fig. 5; Fig. 6). The export-intensive industries survived moderately through the recession compared with the industries that were more dependent on domestic markets (Vuorenmaa, 2003, pp. 4356). The most remarkable negative turn in manufacturing fell on the clothing sector which lost $81 \%$ of its employment in the 1990s (Fig. 6). A small production unit of a larger corporation was closed due to unprofitability and overcapacity, and its production was relocated to lower labour cost countries (Henttinen, 2007). The sawmill and the cardboard company increased labour productivity and as a consequence, many workers were laid off. The cost savings and improvement activities continued after Stora Enso sold its cardboard factory to an international investment group in 2006 (Lieksa, 2009; 2013; Pankaboard, 2013; Fig. 7), but also outsourcing reduced the number of employees in cardboard production. Nevertheless, most jobs remained in the local economy since the outsourcing of the overhaul functions only relocated the jobs in the statistics from the wood-processing industry to the metal products industry (Maintpartner, 2008; Regional Council of North Karelia, 2009). Hence, the increased number of jobs in the manufacturing of metal products in the early 2000 s is only partially explained by the actual increase in jobs, although this industry was seen at the time as a next booster business of the local economy. Several SMEs were active, and prospects for the local companies seemed fairly good inasmuch as the metal products industry was regionally recognised as an essential investment and development industry (Vuorenmaa, 2003). The development of the metal products industry confronted a setback when a major company suspended its production in the area and the production was transferred abroad closer to the growing markets (Hirvonen, 2009). In spite of the efforts and the recovery of the revenues in the metal products industry, the number of jobs remained at a lower level than in the peak years (TE-centre of North Karelia, 2008).

The constant endeavor towards cost-efficiency and improvement of production has also reduced the number of employees in the manufacturing of rubber and plastic products (Fig. 6). Unlike the more diverse local metal products industry, the jobs in the production of rubber and plastic products were mainly dependent on three main companies (Regional Council of North Karelia, 2009). Ownership changes and invention of new products were used as strategies for remaining in the markets for these products. For instance, the production of heavy inner tubes, bicycle tires and shoe soles remained in Lieksa when the nationwide companies sold their branch businesses to a smaller local company in Lieksa (Nokian Renkaat, 2004; Suomen Kumitehdas, 2014; Taloussanomat, 2004). The production lines were coordinated so that their production could complement each other if one line of production was at risk. Nevertheless, in spite of increasing competiveness, the total number of employees has kept on falling in these industries (Taloussanomat, 2014; YLE, 2009). 


\section{Back to local natural resources?}

What would be the sixth industry life cycle? The utilization of natural resources is stressed again in current development strategies of the town and the sub-region, but with a new emphasis: forests as a resource for renewable energy, specialized agriculture as a resource for the food industry, and nature and wilderness as resources for tourism and other similar industries (Lieksa, 2014; PIKES, 2014). Various bioenergy projects, such as biorefinery and bioterminal, are planned (Huikuri and Okkonen, 2012), the Koli national park is under constant development in order to fulfill the requirements for diversifying customers, and the food industry aims, for instance, to penetrate into the market of ready meals and specialized dairy products.

However, a growth in the use of local natural resources is hardly a sufficient solution as the new industries relying on the extraction and utilization of local natural resources, most importantly bioenergy production, do not provide enough jobs for the locals. It has been estimated that the production of bioenergy could employ about 30 employees in Lieksa (Vatanen, 2010), although much higher estimates have recently been presented (Huikuri and Okkonen, 2012). Low employment effects are to be expected from tourism businesses that seek to utilise natural landscapes as attractions (Vatanen et al., 2012). Contrary to Lapland in the north (Lehtonen and Tykkyläinen, 2014; Vatanen et al., 2014), agro-forest areas in Eastern Finland have not attracted significant numbers of tourists, and their attractions are not very suitable for mass tourism which would be necessary in the high-cost area. It would appear that there are no strong epoch-making market demands for the industries in Lieksa in sight; no new, significant initial advantages emerging; and no financial resources from the state or the EU for creating new constructed advantages. Hence, Lieksa, as a towns in a declining resource region, is struggling to maintain any form of resilience.

\section{Discussion}

The local economy of the town of Lieksa, with its rural hinterland, has been very dependent on exports during the first four waves of its industrial development. The significance of local-global links has changed according to global demand, ownership changes in industries and transformations of the national development policies. The national scale governmental policies had a strong role earlier in the colonization of the wilderness areas and in resource-based industrialization, that were promoted as parts of larger scale nation and region-building processes. However, the impact of the state on developing economic activities has diminished over time. The state has withdrawn from peripheries in the same way as in Canada (Markey et al., 2008). Instead of a sign of development, currently the presence of the public sector in peripheries is largely due to the former growth in municipal services and a relatively large proportion of the population living on welfare.

In addition to the impacts of global demand, various policy measures have shaped economic landscapes in resource peripheries. In the Finnish economy, there were several crises and turning points that had local effects during the two centuries. Economic growth diffused to the peripheries in the late $19^{\text {th }}$ century in part due to easy access to the Russian market, but this connection came to an end abruptly. The independence of the Republic of Finland from Russia in 1917 led to a closed border, an expansion of small-scale farming and the reorientation of the exports of industrial produce to the Western markets. The local economy was re-oriented and renewed relatively successfully. The next major growth period took place after the Second World War. Post-war colonization increased growth in the forestry sector as the state strived to mobilize the labour resources to work in the peripheries and intensified the use of forest resources in remote areas. The main response at the national and local scales to the end of the colonization period and increasing rural unemployment was reorientation towards a more diversified economy. The era of strong regional policy since the mid-1960s, that was seen as a way to overcome the crisis of the local economy, led to the growth of the light industry. It also soon turned to a decline which was accelerated by closures of the most footloose plants following the depression of the early 1990s. At present, the long term forest industry cycle and the manufacturing cycle of the 1970s still continue, although their contribution to local employment has declined significantly. Generally, much of the rural job loss in Finland is explained by growing labour productivity in resource-based sectors, where the same or a larger 
output is obtained by less work. As the competitive advantage of remote, resource-based peripheries is limited to the use of local natural resources, the localities are usually uncompetitive for other industrial activities (Lehtonen and Tykkyläinen, 2010b; Polèse and Shearmur, 2006 ). A decline in towns and rural areas is the inevitable outcome if the dominant industries weaken due to poor adaptive capacity.

The reactions to the crises have included the shift of labour from one sector to another and gradual depopulation. During the colonization periods, Lieksa was a labour-absorbing municipality, but when the support for the mobilization of the population for the more intensive use of the land and forests ended, rural depopulation started and has continued since. During the period when forest industrial production was very competitive, resource-based towns such as Lieksa were wealthy compared to the surrounding localities (Lehtonen and Tykkyläinen, 2010a). As labour contracts in the forest industry are universally valid across the country, salaries and wages are not very flexible locally, increasing the pressure for an increase in productivity. In this way, however, the income level remained higher in mill communities than their surrounding areas for decades. The outcome of the restructuring of the forest industry has been a relative decline of well-being in industrial localities compared with the neighbouring rural areas.

The replacement, by forestry machines and harvesters, of small scale farming and manual forestry work that provided a basis for the spatial structure for decades has led to the strong growth in the productivity of forestry. As the article has illustrated, resilience can be observed in the transition phase of the local economy when ways to deal with external and internal pressures had to be found. As a solution, the industrial estate provided new jobs, which can be seen as way for reorienting the local economy by promoting new lines of industries (Martin, 2012). Although the local economy diversified, it did not depart, however, from the industrial traditions of providing employment. The resilience at the time was essentially dependent on national scale policy measures and the capacities brought to the local scale from the national scale, even if the local industrial tradition provided the basis for the rescue activities. The policy measures can be seen as been partially successful at the time, as they brought about a regrowth in the number of jobs. The problem for the local economy, however, was that the policy measures from the above did not last, and without the national support the new industries were not able to maintain competitiveness. Hence a new crisis emerged rather soon. As the forest industries were further modernized and the diversification of the local industrial basis could not compensate for job losses, depopulation has been the way for local adaptation, with the population in Lieksa declining to the same level as in the early $20^{\text {th }}$ century.

The growth of the services sector regarding the positions of employment it provides and the fact that as an employer it surpasses all other industries, including manufacturing and forestry, could under certain circumstances be seen as a form of renewal of the local economy (Martin, 2012). In the case study presented in this article the conclusion must be, however, that this is not the case. The services provided at the local scale have been mostly a result of policies designed and implemented at the scale of the nation-state. For the locality, they appear to be entirely exogenous in origin, based on the expansion of the Nordic welfare state model. Most importantly, the original aim of the welfare services was not to substitute the declining forestry and manufacturing industries, but to provide health care and other well-being for the existing populations. Therefore, even if there are some private sector services that have been designed for tourists, the bulk of the employment positions in services cannot be understood as leading to a renewal of the local economy. The main aim of these policies has also not been to diversify the local industrial structure but rather to add a component to the existing structure that supports the local population in getting welfare services. For an improved understanding of the variations of regional and local resilience, it would be useful, on a general level, to conceive of such situations as cases of parallel development of sectors, where an emerging industry supplements the existing industries but the development does not lead to a reorientation or renewal of the local economy.

Since the late 1960s the main instruments of the Finnish development policy have been regional policy and a collection of local development policy measures. Agricultural policy has regulated farming. The membership of the EU brought additional instruments, such as structural 
funds and LEADER-policy measures, but their impacts have not succeeded in changing the tide. During the entire period from the 1960s until the present Lieksa has depopulated, which indicates that these policies have not succeeded in preventing rural decline. When such a decline is inevitable, gradual adaptation in the declining parts of the economy is a reasonable alternative (Sousa and Pinho, 2015). There has been rural renewal, such as rapid modernization and growth of small businesses, but it has been insufficient from the viewpoint of job growth. Success stories are very rare, and current policy measures are insufficient in generating growth which would prevent the rural decline.

The disadvantages affecting rural areas will not disappear without fundamental changes in spatial cost structures in relation to productivity. As cold, remote peripheral areas are not the target areas of young generations (Tuhkunen, 2007) or amenity migration (Partridge, 2010), there are no factors that could compensate for the high costs of remoteness. According to Lehtonen and Tykkyläinen (2012), through investments in innovations, technologies, and labour quality and skills, developing industries benefiting from rural economies and the promotion of life-style changes could slow down rural job decline. A more passive form of adaptation would consist in an increase in the flexibility of factor prices outside urban centres, which would lead to better price competiveness and a higher demand for labour. However, it may remain less beneficial for a renewal of local economies and for a creation of new industry life cycles. This is nothing new in the context of current economic literature, but as the state and the EU off-load a great deal of development responsibilities on regional and local actors, no large nation-state level governmental initiatives can be expected in the current economic climate. Thus, in terms of policies and strategies for dealing with change, adaptation is supposed to emerge endogenously in the declining peripheries.

\section{Conclusions}

The case study of Lieksa unveiled five past industry life cycles (Fig. 10) from the early $19^{\text {th }}$ century up until today. The first cycle emerged based on lake ore, the second on colonization waves, the third on the development of the processing of the forest resources, the fourth on the industrialization of underdeveloped areas by means of a strong nation-wide regional policy, and the fifth on the services sector that expanded especially due to the implementation of the Nordic welfare state model. Except for the growth of manufacturing and its decline and the heydays of the welfare and state service sector, the cycles have been long, varying from 50 to 80 years. The bell-shaped cycle of manufacturing is shorter and the service sector has been under restructuring. It remains to be seen what will happen to the industrial estate in the future - renewal and re-growth, stagnation or decline.

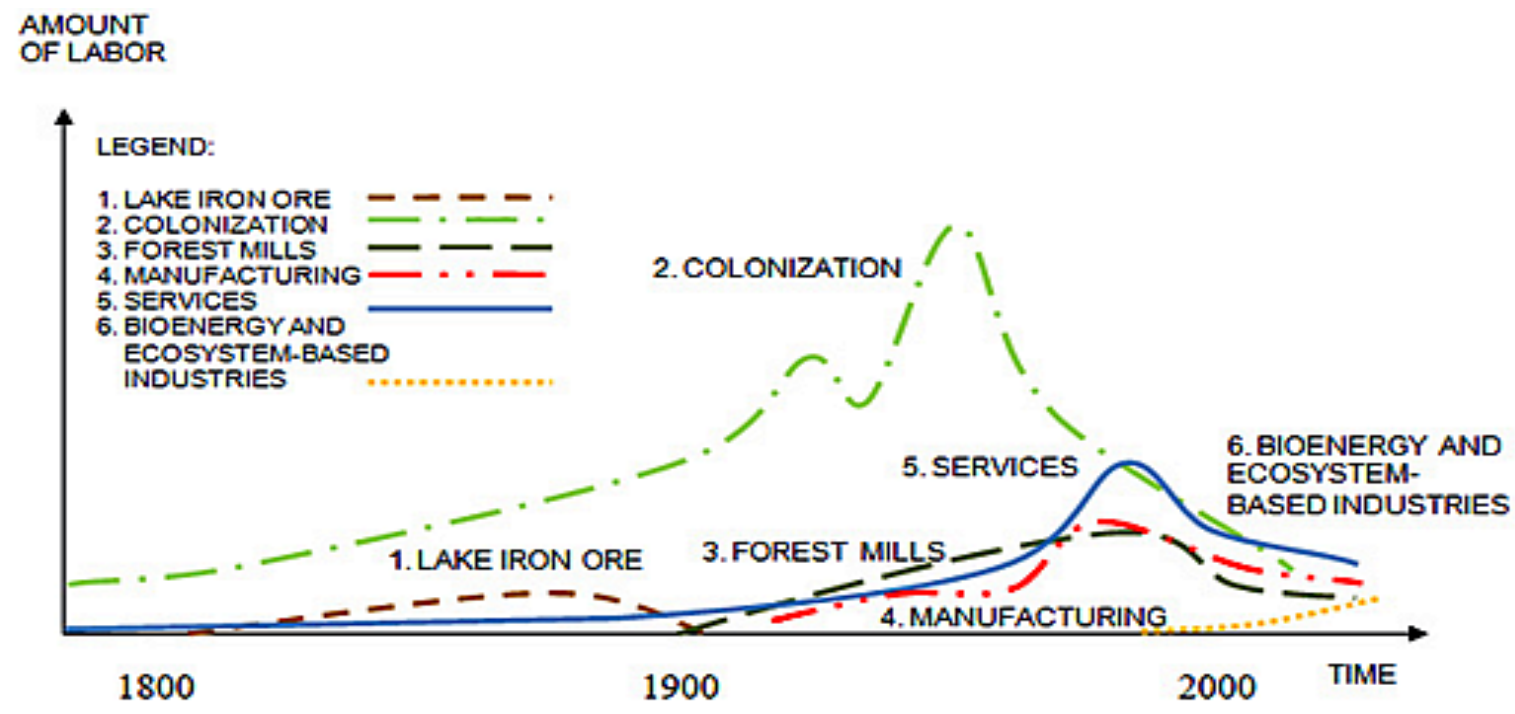

Fig 10. Industry life cycles in Lieksa since the beginning of industrialization. 
The industry life cycles have been overlapping; when one cycle has turned to decline, the locals and other stakeholders have attempted to search for new sources of livelihood. In the phases where resilience can be observed, the shift of the emphasis from one sector to another and always towards newer, more productive technologies have compensated for the loss of mature businesses. In Martin's (2012) terms reorientation and renewal have been the responses in the main. The role of the state has been significant in providing institutional and economic conditions for local resilience and the new development cycles that have emerged as a result. Resilience as capacity for reorientation and renewal has been enabled through institutional regulation, investments in infrastructure and government subsidies, especially in terms of the second and fourth cycles. The fifth cycle was financed mainly by taxpayers. The conditions of the growth of the first, third and fourth cycles originated very much from the global market. The fourth cycle could have also been boosted by the opening up of the European market for Finnish products, but those impacts remained meagre. However, all the policy reactions from "the above" have been based on the capacity of the state and limited to a particular period of time. Hence, policy measures are not automated, but dependent on governmental resources, public spending priorities and decision-making. Markey et al. (2008) give an example of how the state can alter and attenuate government and industry commitments to peripheral areas. That reorientation of regional policy is comparable to what has happened in Finland (Suorsa, 2007).

As different sectors and industries react differently and have different life cycles, successful resilience periods generate industry life cycles originating from the success of enterprises. The first cycle of lake ore has disappeared in full, and a great part of agriculture measured in the number of jobs has disappeared. Similarly, the forestry sector, from logging to final production, has been strongly rationalized and restructured several times. Martin (2012) pays attention to how a region returns to be vital. However, this is not always the way economic transformations in a region or locality take. There are many devolutionary processes going on, especially in the stages of adaptation. Inter-cyclical transformation is full of risks of failures, and that the region remains unattractive to new, potential industries may prevent resilience in the form of reorientation or renewal. For instance, the short wave of footloose industrialization is over in Lieksa and there are no signs of a significant recovery. The new industry life cycles of bioenergy and tourism are often mentioned in regional and local plans and newspapers as a panacea, but their realization is risky and dependent on the various factors of development.

Many parallel economic processes exit in evolving localities. There have always been devolutionary processes in the existing local economies, meaning that some enterprises and industries vanish from a locality. Some organizations and occupations disappear, and development in that part of the economy is devolutionary (Tykkyläinen, 2012). During crisis periods there are strong devolutionary processes which various adaptive processes such as cost savings attempt to relieve, but also evolutionary processes promoting and enhancing the emergence of new economic activities. The long-term results of such an evolution are uncertain and unpredictable.

\section{Acknowledgement}

This study was supported by a grant from the North Karelia Regional Fund of the Finnish Cultural Foundation (grant for research: Perifeerisen maaseudun elämäntavan uusiutuminen).

\section{References}

[1] Aarnio, J. (1999). Kaskiviljelystä metsätöihin: Tutkimus Pielisjärven kruununmetsistä ja kruununmetsätorppareista vuoteen 1910. University of Joensuu. Department of Geography, publications 4.

[2] Adger, N. W. (2000). Social and ecological resilience: Are they related? Progress in Human Geography, 24 (3), 347-364. Doi: 10.1191/030913200701540465. 
[3] Brezis, E. \& Krugman, P. (1997). Technology and the life cycle of cities. Journal of Economic Growth, 2 (4), 369-83. Doi: 10.1023/A:1009754704364.

[4] Christopherson, S., Michie, J. \& Tyler, P. (2010). Regional resilience: Theoretical and empirical perspectives. Cambridge Journal of Regions, Economy and Society, 3, 3-10. Doi: $10.1093 /$ cjres/rsq004.

[5] Cooke, P. \& Leydesdorff, L. (2006). Regional development in the knowledge-based economy: The construction of advantage. Journal of Technology Transfer, 31 (1), 5-15. Doi: 10.1007/s10961-005-5009-3.

[6] Danson, M. \& de Souza, P. (2012). Nations and regions in Northern Europe. In: Danson, M. \& de Souza, P. (eds.), Regional Development in Northern Europe: Peripherality, Marginality and Border Issues, Regional Studies Association, Serie Regions and Cities, Abingdon: Routledge, pp. 98-117.

[7] Edenhoffer, K. \& Hayter, R. (2013). Restructuring on a vertiginous plateau: The evolutionary trajectories of British Columbia's forest industries 1980 - 2010. Geoforum, 44, 139-151. Doi: 10.1016/j.geoforum.2012.10.002.

[8] Engle, N. L. (2011). Adaptive capacity and its assessment. Global Environmental Change, 21, 647-656. Doi: 10.1016/j.gloenvcha.2011.01.019.

[9] Enso Oyj (1997). Annual Report 1997. Retrieved from http://web.lib.hse.fi/FI/yrityspalvelin/pdf/1997/eenso.pdf (accessed 19.12.2013).

[10] Eskelinen, H. (2001). Aluepolitiikka rautahäkissä. Kunnallisalan kehittämissäätiön Polemiasarjan julkaisu 41. http://www.kaks.fi/sites/default/files/Polemia\%2041.pdf (accessed 18.3.2014).

[11] Espon Project 2.1.3. (2006). The territorial impact of CAP and rural development policy. http://www.espon.eu/main/Menu_Projects/Menu_ESPON2006Projects.html (accessed 3.3.2010).

[12] Finnish Border Guard (2010). Annual Report 2010. http://live.grano.fi/tuotanto/r/rajavartiolaitos_2010/(accessed 7.11.2010).

[13] Folke, C. (2006). Resilience: The emergence of a perspective for social-ecological systems $\begin{array}{llll}\text { analyses. Global Environmental } & \text { 253-267. }\end{array}$ Doi: 10.1016/j.gloenvcha.2006.04.002.

[14] Freudenburg, W. \& Gramling, R. (1994). Natural resources and rural poverty: A closer look. Society and Natural Resources, 7 (1), 5-22. Doi: 10.1080/08941929409380841.

[15] Fujita, M. \& Krugman, P. (2004). The new economic geography: Past, present and future. Papers of Regional Science, 83 (1), 139-164. Doi: 10.1007/s10110-003-0180-0.

[16] Gallup, J., Sachs, J. \& Mellinger A. (1999). Geography and economic development. $\begin{array}{lllll}\text { International Regional Science } & \text { Review, } 22 & \text { (2), }\end{array}$ Doi: 10.1177/016001799761012334.

[17] Garretsen, H. \& Martin, R. (2010). Rethinking (new) economic geography models: Taking geography and history more seriously. Spatial Economic Analysis, 5 (2), 127-160. Doi: $10.1080 / 17421771003730729$.

[18] Gløersen, E., Dubois, A., Copus, A. \& Schürmann, C. (2005). Northern peripheral, sparsely populated regions in the European north. Nordregio Report 2005, 4.

[19] Hayter, R. \& Patchell, J. (2011). Economic Geography. An Institutional Approach. Don Mills (Canada): Oxford University Press.

[20] Helminen, V., Nurmio, K., Rehunen, A., Ristimäki, M., Oinonen, K., Tiitu, M., Kotavaara, O., Antikainen, H. \& Rusanen, J. (2012). Kaupungin-maaseudun aluetypologian muodostamisperiaatteet - tekninen menetelmäkuvaus. http://www.ymparisto.fi/download.asp?contentid=135819\&lan= (accessed 18.8.2013). 
[21] Henttinen, A. (2007). Moderni suomalainen: Luhdan ensimmäiset sata vuotta. Lahti: LFashion Group.

[22] Hirvonen, T. (2009). Joensuun seudun sopeutuminen Perloksen tuotannon lopettamiseen. Spatia Centre for Regional Research, Reports 1. https://www.uef.fi/documents/1145887/1146339/rap2009_1.pdf/defc5877-c264-4676-a5f8f6114b0ad539 (accessed 10.3.2014).

[23] Hjerppe, R. (1989). The Finnish economy 1860-1985. Growth and Structural Change. Helsinki: Bank of Finland. Government Printing Office.

[24] Hoving, V. (1961). Enso-Gutzeit Osakeyhtiö 1872 - 1958, vol. II. Helsinki: Frenckellin Kirjapaino Osakeyhtiö.

[25] Huikuri, N. \& Okkonen, L. (2012). Bioenergiaa Pielisen Karjalaan. Joensuu: PohjoisKarjalan ammattikorkeakoulu.

[26] Julkunen, R. (1992). Hyvinvointivaltio käännekohdassa. Tampere: Vastapaino.

[27] Julkunen, R. (2001). Suunnanmuutos: 1990-Iuvun sosiaalipoliittinen reformi Suomessa. Tampere: Vastapaino.

[28] Kangasharju, A. \& Pekkala, S. (2004). Increasing regional disparities in the 1990s: The Finnish experience. Regional Studies, 38 (3), 255-267. Doi: 10.1080/003434042000211097.

[29] Kiander, J. (2001). Laman opetukset: Suomen 1990-luvun kriisin syyt ja seuraukset. Helsinki: Government Institute for Economic Research, Publications 27 (5).

[30] Kitson, M., Martin, R. \& Tyler, P. (2004). Regional competitiveness: An elusive yet key concept? Regional Studies, 38 (9), 991-999. Doi: 10.1080/0034340042000320816.

[31] Kontiainen, H. (2010). Factory manager. Amcor Flexibles Lieksa. Interview 17.8.2010.

[32] Kortelainen, J. (2010). Aluepolitiikka. In: Niemelä, P. (ed.) Hyvinvointipolitiikka, Helsinki: WSOYpro Oy, pp. 346-366.

[33] Kortelainen, J. \& Rannikko, P. (2014). Positionality switch: Remapping resource communities in Russian borderlands, Economic Geography, Doi: 10.1111/ecge.12064 (early view, online).

[34] Kotilainen, J., Eisto, I. \& Vatanen, E. (2015). Uncovering mechanisms for resilience: Strategies to counter shrinkage in a peripheral city in Finland. European Planning Studies 23 (1), 53-68. Doi: 10.1080/09654313.2013.820086.

[35] Kotilainen, J. \& Rytteri, T. (2011). Transformation of forest policy regimes in Finland since the $19^{\text {th }}$ century. Journal of Historical Geography, 37, 429-439. Doi: 10.1016/j.jhg.2011.04.003.

[36] Krugman, P. (1991). Increasing returns and economic geography. Journal of Political Economy, 99 (3), 483-499.

[37] Krugman, P. (1993). First nature, second nature, and metropolitan location. Journal of Regional Science, 33 (2), 129-144. Doi: 10.1111/j.1467-9787.1993.tb00217.x.

[38] Krugman, P. (1998). What's new about the new economic geography? Oxford Review of Economic Policy, 14 (2), 7-17. Doi:10.1093/oxrep/14.2.7.

[39] Kuisma, M. (2006). Metsäteollisuuden maa: Suomi, metsät ja kansainvälinen järjestelmä 1620 - 1920. $2^{\text {nd }}$ edition. Helsinki: Suomalaisen Kirjallisuuden Seuran Toimituksia 1055:1.

[40] Kupiainen, H. (1995). Ihmisten ja yhtiöiden maannälkä: Egyptinkorven ja Nurmijärven maanomistusolot isojaosta nykypäivään. In: Laitinen, E. (ed.) Rintamalta raiviolle, Jyväskylä: Atena, pp. 161-183. 
[41] Leake, N., Adamowicz, W. \& Boxall, P. (2006). An econometric analysis of the effect of forest dependence on the economic well-being of Canadian communities. Forest Science, 52 (5), 595-604.

[42] Lehtonen, O. \& Tykkyläinen, M. (2010a). Tulotason spatiaalinen kaksoispolarisaatio Pohjois-Karjalassa 1996 - 2003. Terra, 122 (2), 63-74.

[43] Lehtonen, O. \& Tykkyläinen, M. (2010b). Kuinka väestö sijoittuu siirryttäessä tietoyhteiskuntaan? - esimerkkinä Itä-Suomi. Yhteiskuntapolitiikka, 75 (5), 500-518.

[44] Lehtonen, O. \& Tykkyläinen, M. (2012). Työpaikkakehityksen alueelliset kehitysprosessit Itä-Suomessa 1994 - 2003 (Spatial processes of job growth in Eastern Finland, 1994 2003). Terra, 124 (2), 85-105.

[45] Lehtonen, O. \& Tykkyläinen, M. (2014). Potential for job creation and resource dependence in rural Finland. European Countryside, 6 (3), 202-224. Doi: 10.2478/euco-2014-0011.

[46] Lieksa (1975). Municipal report of Lieksa 1974 I. Lieksan kirjapaino, Lieksa.

[47] Lieksa (1976). Municipal report of Lieksa 1974 II. Lieksan kirjapaino, Lieksa.

[48] Lieksa (1980). Municipal report of Lieksa 1979. Lieksan kirjapaino. Lieksa

[49] Lieksa (2009). The largest employers of Lieksa 2008. Unpublished summary table.

[50] Lieksa (2012). A List of Active Farms 2011. Unpublished data system printout.

[51] Lieksa (2013). The largest employers of Lieksa 2013. Summary table. http://www.lieksa.fi/Resource.phx/sivut/sivut-lieksa/esittely/lieksansuurimmattyonantajat.htx (accessed 13.12.2013).

[52] Lieksa (2014). The strategy of Lieksa 2020. http://www.lieksa.fi/dman/Document.phx?documentld=qr04114121950536\&cmd=download (accessed 15.3.2014).

[53] Luoma-aho, J. \& Strömberg, H. (2008). Enso-Gutzeit oy, Pankakosken tehtaat. elma.elka.fi/ArkHistory/E062.DOC (accessed 10.3.2014).

[54] Maintpartner (2008). Pankaboard ja Maintpartner allekirjoittivat kunnossapidon kumppanuussopimuksen. http://www.maintpartner.fi/fi/uutisia/uutiset-jatiedotteet/356/pankaboard-ja-maintpartner-allekirjoittivat-kunnossapidonkumppanuussopimuksen.html (accessed 19.3.2014).

[55] Malinen, P. (1998). Yhdentävä maaseutupolitiikka ja paikallinen omaehtoisuus. Maaseudun uusi aika, 2, 22-27.

[56] Malinen, P., Kytölä, L., Keränen, H. \& Keränen, R. (2006). Suomen maaseututyypit 2006. Ministry of Agriculture and Forestry, Publications 7.

http://www.mmm.fi/attachments/mmm/julkaisut/julkaisusarja/5kYqNENOF/MMMjulkaisu200 6_7.pdf (accessed 20.8.2013).

[57] Manyena, S. B. (2006). The concept of resilience revisited. Disasters 30 (4), 434-450. Doi: 10.1111/j.0361-3666.2006.00331.x.

[58] Markey, S., Halseth, G. \& Manson, D. (2006). The struggle to compete: From comparative to competitive advantage in Northern British Columbia. International Planning Studies, 11 (1), 19-39. Doi: 10.1080/13563470600935016.

[59] Markey, S., Halseth, G. \& Manson, D. (2008). Challenging the inevitability of rural decline: Advancing the policy of place in Northern British Columbia. Journal of Rural Studies, 24 (4), 409-421. Doi: 10.1016/j.jrurstud.2008.03.012.

[60] Martin, R. (2012). Regional economic resilience, hysteresis and recessionary shocks. Journal of Economic Geography, 12 (1), 1-32. Doi: 10.1093/jeg/lbr019.

[61] Mikkonen, K. (2002). Competitive advantage of regions and small economic areas: The case of Finland. Fennia, 180 (1-2), 191-198. 
[62] Moisio, S. \& Leppänen, L. (2007). Towards a Nordic competition state? Politico-economic transformation of statehood in Finland, 1965 - 2005. Fennia, 185 (2), 63-87.

[63] Myant, M. \& Drahokoupil, J. (2012). International integration, varieties of capitalism and resilience to crisis in transition economies. Europe-Asia Studies, 64 (1), 1-33. Doi: 10.1080/09668136.2012.635478.

[64] Nokian Renkaat (2004). Nokian Renkaat Oyj myymässä polkupyöränrenkaatliiketoimintansa. http://www.nokianrenkaat.fi/tiedote?id=10340933 (accessed 2.3.2014).

[65] Näsi, J., Lamberg, J-A., Ojala, P. \& Sajasalo, P. (2001). Metsäteollisuusyritysten strategiset kehityspolut: Kilpailu, keskittyminen ja kasvu pitkällä aikavälillä. Helsinki: Metsäalan tutkimusohjelma Wood Wisdom.

[66] Official Statistics Finland (1960 - 1986). Population: Intermunicipal migration. Volume 6 A.

[67] Official Statistics Finland (1979). Väestön elinkeino: Väestö elinkeinon mukaan kunnittain 1880 - 1975, Tilastollisia tiedonantoja 63.

[68] Official Statistics Finland (1982). 201 - Population over 15 years by sex and belonging to labour force 1980. Unpublished data system printout.

[69] Official Statistics Finland (1990). Cencus of Population. Volume 7 C.

[70] Official Statistics Finland (2009). Population projection 2009-2060. http://tilastokeskus.fi/til/vaenn/2009/vaenn_2009_2009-09-30_en.pdf (accessed 12.2.2015).

[71] Official Statistics Finland (2013a). Population structure: Population density by area 1.1.2013. http://pxweb2.stat.fi/database/StatFin/vrm/vaerak/vaerak_en.asp (accessed 4.6.2014).

[72] Official Statistics Finland (2013b). 050 - Employed workforce in area (workplaces) by area, employer sector, occupational status and sex 1987-2011. http://pxweb2.stat.fi/database/StatFin/vrm/tyokay/tyokay_en.asp (accessed 20.4.2014).

[73] Official Statistics Finland (2014a). 010 - Population by area, main type of activity, sex, age and year 1987-2013*. http://pxweb2.stat.fi/database/StatFin/vrm/tyokay/tyokay_en.asp (accessed 10.2.2015).

[74] Official Statistics Finland (2014b). Immigration and emigration by age, sex and area 19872013. http://pxweb2.stat.fi/database/StatFin/vrm/muutl/muutl_en.asp (accessed 10.2.2015).

[75] Official Statistics Finland (2014c). Population according to age (1-year) and sex by area 1980 - 2013. http://pxweb2.stat.fi/database/StatFin/vrm/vaerak/vaerak_en.asp (accessed 11.2.2015).

[76] Official Statistics Finland (2014d). Tuotanto ja työllisyys seutukunnittain 1975-2008*, 20 toimialaa. http://193.166.171.75/database/StatFin/kan/altp/altp_fi.asp (accessed 20.4.2014).

[77] Official Statistics Finland (2015a). Concept and definitions: Economic activity (labour force). http://tilastokeskus.fi/meta/kas/amm_toimi_en.html (accessed 10.2.2015).

[78] Official Statistics Finland (2015b). Concept and definitions: Intermunicipal net migration. http://tilastokeskus.fi/til/muut//kas_en.html (accessed 11.2.2015).

[79] Official Statistics Finland (2015c). Concept and definitions: Unemployment rate. http://tilastokeskus.fi/meta/kas/tyottomyysaste_en.html (accessed 11.2.2015).

[80] Official Statistics Finland (2015d). Concept and definitions: Employment. http://stat.fi/meta/kas/tyollisyys_en.html (accessed 17.2.2015).

[81] Oinonen-Edén, E. (1991). Pielisjärven ja Juuan historia 1811 - 1864. Pielisjärven historia III. Lieksan kaupunki, Juuan kunta, Pielisjärven ja Viekijärven seurakuntayhtymä. 
[82] Overdevest, C. \& Green, G. (1995). Forest dependence and community well-being: A segmented market approach. Society \& Natural Resources: An International Journal, 8 (2), 111-131. Doi: 10.1080/08941929509380906.

[83] Palokas, U. (2002). Kevätniemen saha 100 vuotta: Kevätniemen saha 1902-2002. Lieksa: Vapo Timber.

[84] Pankaboard (2013). History. http://www.pankaboard.com/history.php (accessed 19.12.2013).

[85] Pankakoski Board Mill (1996). The number of employees. Enso-Gutzeit Oy, Employee statistics. Central Archives for Finnish Business Records.

[86] Partridge, M., Bollman, R., Olfert, M. \& Alasia, A. (2007). Riding the wave of urban growth in the countryside: Spread, backwash or stagnation? Land Economics, 83 (2), 128-152. Doi: 10.3368/le.83.2.128.

[87] Partridge, M. D. (2010). The duelling models: NEG vs amenity migration in explaining.

[88] US engines of growth. Papers in Regional Science, 89 (3), 513-536. Doi: 10.1111/j.14355957.2010.00315.x.

[89] Patriquin, M., Parkins, J. \& Stedman, R. (2007). Socio-economic status of boreal communities in Canada. Forestry, 80 (3), 279-291. Doi: 10.1093/forestry/cpm014.

[90] Peltoniemi, M. (2011). Reviewing industry life-cycle theory: Avenues for future research. International Journal of Management Review, 13, 349-375. Doi: 10.1111/j.1468_2370.2010.000295.x.

[91] PIKES (2014). The economic development strategy of Pielinen Karelia 2014-2017. http://www.pikes.fi/documents/757708/1416317/Pielisen+Karjalan+Elinkeinostrategia+2014 -2017_final.pdf/74ea804a-b6f6-47e6-8f03-d98fee4353c8 (accessed 12.2.2015).

[92] Polèse, M. \& Shearmur, R. (2004). Is distance really dead? Comparing location patterns over time in Canada. International Regional Science Review, 27 (4), 431-457. Doi: $10.1177 / 0160017604267637$.

[93] Polèse, M. \& Shearmur, R. (2006). Why some regions will decline: A Canadian case study with thoughts of local development strategies. Papers in Regional Science 83 (1), 23-46. Doi:10.1111/j.1435-5957.2006.00024.x.

[94] Potter, A. \& Watts, H. D. (2011). Evolutionary agglomeration theory: Increasing returns, diminishing returns, and the industry life cycle. Journal of Economic Geography, 11 (3), 417-455. Doi: 10.1093/jeg/lbq004.

[95] PRH (2014). Company Information: Enso-Gutzeit Oy. National Board of Patents and Registration of Finland.

https://virre.prh.fi/portal/dt?userLang=en\&provider=layout\&action=content $\quad$ (accessed 7.4.2014).

[96] Pääkkönen, E. (2013). Ruukin aikaan: Pankakosken harkkohytin historia 1820 - 1911. Tampere: Mediapinta.

[97] Rannikko, P. (1999). Savottojen ja väestökadon Suomi. In: Löytönen, M. \& Kolbe, L. (eds.) Suomi: Maa, kansa ja kulttuuri. Jyväskylä: Suomen Kirjallisuuden Seuran Toimituksia 753, pp. 211-221.

[98] Rannikko, P. (2014). Maaseutuyhteiskunnan muutos. In: Björn, I. (ed.) Rajan maakunta: Pohjois-Karjalan historia 1939 - 2014, Helsinki: Suomalaisen Kirjallisuuden Seura, pp. 197219.

[99] Regional Council of North Karelia (2009). Database of industry 1980 - 2008. Unpublished summary table. 
[100] Saarelainen, A. (1995). Raivaussavuista euroaikaan. Pielisjärven maaseutu yhteiskunnan muutoksissa 1945 - 1995. In: Laitinen, E. (ed.) Rintamalta raiviolle, Jyväskylä: Atena, pp. 184-238.

[101] Sachs, J. \& Warner, A. (1997a). Fundamental sources of long-run growth. American Economic Review, 87 (2), 184-188. Doi: 10.1111/j.1435-5957.2006.00024.x.

[102] Sachs, J. \& Warner, A. (1997b). Natural Resource Abundance and Economic Growth. Cambridge: Center for International Development and Harvard Institute for International Development, Harvard University.

[103] Sajasalo, P. (2003). Strategies in Transition: The Internationalization of Finnish Forest Industry Companies. Jyväskylä Studies in Business and Economics 23.

[104] Sippola, M. (2010). Kehitysalueista aluekehitykseen. Suomen virallisen aluepolitiikan 30 ensimmäistä vuotta 1966 - 1995. Työ- ja elinkeinoministeriön julkaisuja. Alueiden kehittäminen 31/2010.

[105] Smith, D. (1981). Industrial Location. $2^{\text {nd }}$ edition. New York: John Wiley \& Sons Inc.

[106] Sousa, S. \& Pinho, P. (2015). Planning for shrinkage: Paradox or paradigm. European Planning Studies, 23 (1), 12-32. Doi: 10.1080/09654313.2013.820082.

[107] Stedman, R., Parkins, J. \& Beckley, T. (2004). Resource dependence and community wellbeing in rural Canada. Rural Sociology, 69 (2), 213-234. Doi: 10.1526/003601104323087589.

[108] Stedman, R., Parkins, J. \& Beckley, T. (2005). Forest dependence and community wellbeing in rural Canada: Variation by forest sector and region. Canadian Journal of Forest Research, 35 (1), 215-220. Doi: 10.1139/x04-140.

[109] Stora Enso Oyj (2014). History. http://www.storaenso.com/about/history (accessed 7.4.2014).

[110] Suomen Kumitehdas (2014). Yli 80 vuotta Reinojen historiaa. http://www.reinokauppa.fi/contact.php (accessed 2.3.2014).

[111] Suorsa, K. (2007). Regionality, innovation policy and peripheral regions in Finland, Sweden and Norway. Fennia, 185 (1), 15-29.

[112] Taloussanomat (2004). Nokian polkupyöränrenkaat ja saapastehdas samaan yhtiöön. http://www.taloussanomat.fi/arkisto/2004/10/02/nokian-polkupyoranrenkaat-jasaapastehdas-samaan-yhtioon/200430181/12 (accessed 2.3.2014).

[113] Taloussanomat (2014). Suomen Rengastehdas Oy. http://yritys.taloussanomat.fi/y/suomen-rengastehdas-oy/lieksa/1920725-5/） (accessed 7.2.2014).

[114] TE-centre of North Karelia (2008). Pohjois-Karjala talouskatsaus 1/2008. http://www.josek.fi/files/file/Talouskatsaus_1_2008.pdf (accessed 10.3.2014).

[115] Tervo, H. (2005). Regional Policy Lessons from Finland. In: Felsenstein, D. \& Portnov, B. A. (eds.) Regional Disparities in Small Countries, Series: Advantages in Spatial Science, Berlin: Springer, pp. 267-282.

[116] Tervo, H. (2009). Centres and peripheries in Finland: Granger causality tests using panel data. Spatial Economic Analysis, 4 (4), 377-390. Doi: 10.1080/17421770903317652.

[117] Tike (2013). Statistics of active farms in Lieksa 1990 - 2010. Agricultural Statistics, Farm Register. Information Centre of the Ministry of Agriculture and Forestry.

[118] Tuhkunen, A. (2007). Between Location and a Sense of Place. Tampere: Acta Universitatis Tamperensis, 1207.

[119] Tykkyläinen, M. (1992). Solutions to mine closure in Outokumpu. In: Neil, C., Tykkyläinen, M. \& Bradbury, J. (eds.) Coping with Closure: An International Comparison of Mine Town Experiences, London \& New York: Routledge, pp. 225-246. 
[120] Tykkyläinen, M. (1995). Asutustoiminnan taloudelliset vaikutukset. In: Laitinen, E. (ed.) Rintamalta raiviolle: Sodanjälkeinen asutustoiminta 50 vuotta, Jyväskylä: Atena, pp. 139158.

[121] Tykkyläinen, M. (2012). Community development as an evolutionary process in remote resource-based areas. In: Häyrynen, S., Turunen, R. \& Nyman, J. (eds.) Locality, Memory, Reconstruction: The Cultural Challenges and Possibilities of Former SingleIndustry Communities, Newcastle: Cambridge Scholars Publishing, pp. 254-272.

[122] Vatanen, E. (1986). Pohjois-Karjalan teollisuus 1910 - 1982. Unpublished research archive material.

[123] Vatanen, E. (2010). Lieksa - luonnonvaroista riippuvainen kaupunki. In: Kotilainen, J. \& Eisto, I. (eds.) Luonnonvarayhdyskunnat ja muuttuva ympäristö - resilienssitutkimuksen näkökulmia Itä-Suomeen, Joensuu: Publications of the University of Eastern Finland, Reports and Studies in Social Sciences and Business Studies 2, pp. 41-54.

[124] Vatanen, E., Eisto, I. \& Rannikko, P. (2012). Luontopalvelut ja matkailu syrjäisen maaseudun elinkeinojen uudistajana: Tapaus Lieksa. Kunnallistieteellinen aikakauskirja, 2, 89-113.

[125] Vatanen, E., Ovaskainen, V. \& Hyppönen, M. (2014). Luontomatkailu alue- ja paikallistaloudessa. In: Tyrväinen, L., Kurttila, M., Sievänen, T. \& Tuulentie, S. (eds.) Hyvinvointia metsästä. Helsinki: Suomalaisen Kirjallisuuden Seura, pp. 153-162.

[126] Virkkala, S. (1994). Economic restructuring and regional development in Finland. In: Doling, J., Koskiaho, B. \& Virkkala, S. (eds.) Restructuring in Old Industrial Towns in Finland, University of Tampere, Department of Social Policy and Social Work, Research Report Serie A 6, pp. 69-103.

[127] Vuorenmaa, R. (2003). 30 vuotta: Lieksan Teollisuuskylä Oy, Lieksa: Lieksa Development Agency.

[128] Walker, B. \& Salt, D. (2006). Resilience Thinking. Sustaining Ecosystems and People in a Changing World. Washington: Island Press.

[129] Wilson, G. A. (2012). Community Resilience and Environmental Transitions. London: Routledge.

[130] YLE (2009). Aino ja Reino pitävät Kumitehtaan pinnalla. Finnish Broadcasting Company. http://yle.fi/uutiset/aino_ja_reino_pitavat_kumitehtaan_pinnalla/5283684 (accessed 2.3.2014).

[131] Yli-Jokipii, P. \& Koski, A. (1995). The changing pattern of Finnish regional policies. Fennia, 173 (2), 53-67. 